\title{
A double peak in the seasonality of California's photosynthesis as observed from space
}

\author{
Alexander J. Turner ${ }^{1,2,3}$, Philipp Köhler ${ }^{4}$, Troy S. Magney ${ }^{3,4,5}$, Christian Frankenberg ${ }^{3,4}$, Inez Fung ${ }^{1}$, and \\ Ronald C. Cohen ${ }^{1,2}$ \\ ${ }^{1}$ Department of Earth and Planetary Sciences, University of California, Berkeley, CA 94720, USA \\ ${ }^{2}$ College of Chemistry, University of California, Berkeley, CA 94720, USA \\ ${ }^{3}$ Jet Propulsion Laboratory, California Institute of Technology, Pasadena, CA 91109, USA \\ ${ }^{4}$ Division of Geological and Planetary Sciences, California Institute of Technology, Pasadena, CA 91226, USA \\ ${ }^{5}$ Department of Plant Sciences, University of California, Davis, CA 95616, USA
}

Correspondence: Alexander J. Turner (alexjturner@berkeley.edu)

Received: 24 September 2019 - Discussion started: 26 September 2019

Revised: 16 December 2019 - Accepted: 6 January 2020 - Published: 29 January 2020

\begin{abstract}
Solar-induced chlorophyll fluorescence (SIF) has been shown to be a powerful proxy for photosynthesis and gross primary productivity (GPP). The recently launched TROPOspheric Monitoring Instrument (TROPOMI) features the required spectral resolution and signal-to-noise ratio to retrieve SIF from space. Here, we present a downscaling method to obtain $500 \mathrm{~m}$ spatial resolution SIF over California. We report daily values based on a $14 \mathrm{~d}$ window. TROPOMI SIF data show a strong correspondence with daily GPP estimates at AmeriFlux sites across multiple ecosystems in California. We find a linear relationship between SIF and GPP that is largely invariant across ecosystems with an intercept that is not significantly different from zero. Measurements of SIF from TROPOMI agree with MODerate Resolution Imaging Spectroradiometer (MODIS) vegetation indices - the normalized difference vegetation index (NDVI), enhanced vegetation index (EVI), and near-infrared reflectance of vegetation index $\left(\mathrm{NIR}_{\mathrm{V}}\right)$ - at annual timescales but indicate different temporal dynamics at monthly and daily timescales. TROPOMI SIF data show a double peak in the seasonality of photosynthesis, a feature that is not present in the MODIS vegetation indices. The different seasonality in the vegetation indices may be due to a clear-sky bias in the vegetation indices, whereas previous work has shown SIF to have a low sensitivity to clouds and to detect the downregulation of photosynthesis even when plants appear green. We further decompose the spatiotemporal patterns in the SIF data based on land cover. The double peak in the seasonality of Califor-
\end{abstract}

nia's photosynthesis is due to two processes that are out of phase: grasses, chaparral, and oak savanna ecosystems show an April maximum, while evergreen forests peak in June. An empirical orthogonal function (EOF) analysis corroborates the phase offset and spatial patterns driving the double peak. The EOF analysis further indicates that two spatiotemporal patterns explain $84 \%$ of the variability in the SIF data. Results shown here are promising for obtaining global GPP at sub-kilometer spatial scales and identifying the processes driving carbon uptake.

\section{Introduction}

Photosynthesis is the process by which plants and other organisms use sunlight to synthesize carbon dioxide $\left(\mathrm{CO}_{2}\right)$ and water to glucose and oxygen. Accurate knowledge of gross primary productivity (GPP) through photosynthesis is crucial for understanding the land-atmosphere carbon exchange, which is one of the largest and most uncertain aspects of the global carbon cycle (IPCC, 2013; Anav et al., 2015; USGCRP, 2018). This uncertainty in the land-atmosphere carbon exchange has led to long-standing questions regarding the magnitude of the Northern Hemispheric terrestrial carbon sink and how it has changed over the past few decades (e.g., Tans et al., 1990; Ballantyne et al., 2012; Ciais et al., 2019). As such, methods of inferring GPP are of great interest to the scientific community. 
Previous work estimating regional or global-scale GPP has typically relied on biosphere models (e.g., the early work on SiB2 from Sellers et al., 1986), used remote-sensing measurements in Monteith light-use efficiency models with scalings for different ecosystems and climatic conditions (e.g., Monteith, 1972; Mahadevan et al., 2008), or attempted to back out GPP from $\mathrm{CO}_{2}$ flux inversions (e.g., CarbonTracker from Peters et al., 2007). The advent of global remotesensing observations of solar-induced chlorophyll fluorescence (SIF) represents a breakthrough in our ability to constrain photosynthetic activity from space. This is because a number of studies have shown SIF to be a powerful proxy for photosynthesis both in laboratory environments (e.g., Baker, 2008) and at larger spatial scales (e.g., Frankenberg et al., 2011a; Parazoo et al., 2014; Yang et al., 2015, 2017; Y. Sun et al., 2017, 2018; Magney et al., 2019a). During the initial stage of photosynthesis, absorbed sunlight excites chlorophyll $a$ molecules. The primary pathways for de-excitation are via photochemistry or non-photochemical quenching, the latter of which dissipates excess energy as heat when the plant does not have the capacity for photosynthesis (i.e., under stress). However, a small fraction dissipates as heat or is re-emitted as fluorescence and can be measured by remote sensing. This remote-sensing retrieval is termed SIF.

The first global space-borne measurements of SIF were made by Frankenberg et al. (2011b) and Joiner et al. (2011) using observations from the Japanese Greenhouse Gases Observing Satellite (GOSAT) instrument (Kuze et al., 2009). Since then, SIF has been retrieved from other space-borne instruments such as the Global Ozone Monitoring Experiment2 (GOME-2) on the MetOp-A satellite, Scanning Imaging Absorption Spectrometer for Atmospheric Chartography (SCIAMACHY) on the Envisat satellite, the Orbiting Carbon Observatory-2 (OCO-2) satellite, and TROPOspheric Monitoring Instrument (TROPOMI) on the Sentinel-5 Precursor satellite (Frankenberg et al., 2011a, b, 2012, 2014; Joiner et al., 2011, 2012, 2013, 2014, 2016; Guanter et al., 2012, 2015; Köhler et al., 2015, 2018). A number of upcoming satellite missions such as FLEX (Drusch et al., 2017) and TEMPO (Zoogman et al., 2017) will also measure SIF at higher spatial and temporal resolution. Efforts are underway to create a multi-decadal SIF record using different spaceborne instruments (Parazoo et al., 2019), and a few groups have utilized machine learning techniques to create spatially continuous SIF datasets at $0.05^{\circ} \times 0.05^{\circ}$ resolution (Zhang et al., 2018; Yu et al., 2019; Li and Xiao, 2019). Mohammed et al. (2019) presents a detailed review of different remotesensing techniques for retrieving SIF from space-borne measurements.

Some work has shown SIF to be a better measure of carbon uptake than other vegetation indices that look at canopy "greenness". This is, in part, because indices like the normalized difference vegetation index (NDVI) are a measure of photosynthetic capacity (Sellers, 1985), whereas SIF is a measure of the photosynthetic activity and is coupled to

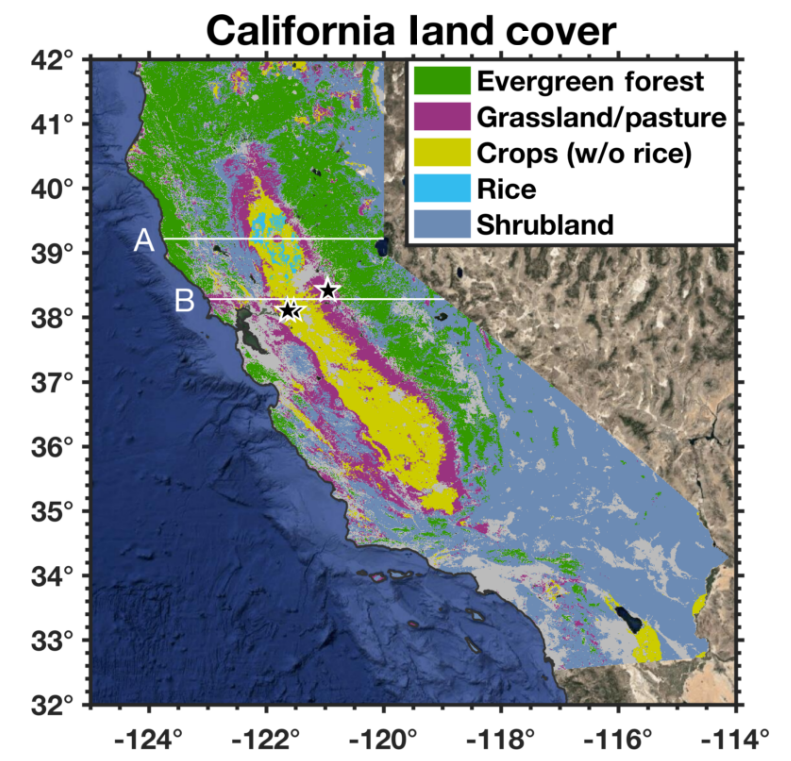

Figure 1. Land cover in California from the 2018 USDA CropScape database (USDA, 2018). Resolution has been degraded from the native $30 \mathrm{~m}$ resolution to $500 \mathrm{~m}$ for comparison with TROPOMI data. Coloring indicates that a land type makes up more than $50 \%$ of the $500 \mathrm{~m}$ grid cell. White lines are the locations of two transects across California for Hovmöller diagrams: $39.218^{\circ} \mathrm{N}$ (transect A) and $38.282^{\circ} \mathrm{N}$ (transect B). Black stars show the location of six AmeriFlux sites: Bouldin Island $\left(38.1090^{\circ} \mathrm{N}, 121.5350^{\circ} \mathrm{W}\right.$; US-Bi2), Tonzi Ranch (38.4316 ${ }^{\circ} \mathrm{N}, 120.9660^{\circ} \mathrm{W}$; US-Ton), Vaira Ranch $\left(38.4133^{\circ} \mathrm{N}, 120.9507^{\circ} \mathrm{W}\right.$; US-Var), Twitchell Island West Pond $\left(38.1074^{\circ} \mathrm{N}, 121.6469^{\circ} \mathrm{W}\right.$; US-Tw1), Twitchell Island East End $\left(38.1030^{\circ} \mathrm{N}, 121.6414^{\circ} \mathrm{W}\right.$; US-Tw4), and Twitchell Island East Pond $\left(38.1072^{\circ} \mathrm{N}, 121.6426^{\circ} \mathrm{W}\right.$; US-Tw5).

the radiation regime. For example, Luus et al. (2017) showed that the seasonal cycle of a biosphere model driven by SIF agreed with measurements of $\mathrm{CO}_{2}$, whereas the seasonal cycle from the model driven by the enhanced vegetation index (EVI) was markedly different from the $\mathrm{CO}_{2}$ observations. Joiner et al. (2011) showed that the seasonal cycles of SIF and EVI agree in some regions but not others. Walther et al. (2016) showed a decoupling of the photosynthesis and greenness dynamics in boreal evergreen forests by comparing SIF and EVI to model estimates of GPP, with SIF better capturing the seasonality of both deciduous broadleaf and evergreen needleleaf forests. Again, this is likely due to SIF capturing photosynthetic activity rather than photosynthetic capacity. More recently, Magney et al. (2019a) demonstrated a mechanistic link between SIF and GPP over the course of a year in a winter-dormant Northern Hemisphere conifer forest, despite retaining chlorophyll through the winter. Magney et al. (2019a) highlighted the potential for new satellite measurements of SIF from TROPOMI and OCO-2 to track GPP at coarse spatial resolution $\left(3.5 \times 7 \mathrm{~km}^{2}\right)$.

Here, we present an oversampling and downscaling method to obtain daily estimates of SIF at $500 \mathrm{~m}$ resolution. 
To our knowledge, this is the highest resolution SIF dataset from satellite measurements. We then compare this downscaled $500 \mathrm{~m}$ SIF data to AmeriFlux sites across the state of California to assess the relationship between SIF and GPP. We finish by decomposing California's spatiotemporal patterns of photosynthesis and carbon uptake into the dominant modes using empirical orthogonal functions (EOFs). Here, we focus on California because there are a number of eddy flux towers and it encompasses a range of diverse ecosystems including deciduous and evergreen forests, irrigated croplands, and grasslands (see Fig. 1).

\section{Measurements of SIF, vegetation, and GPP}

\subsection{Satellite measurements of SIF from TROPOMI}

TROPOMI (Veefkind et al., 2012) is a nadir-viewing imaging spectrometer with bands in the UV, visible, near-infrared, and shortwave infrared aboard the Sentinel-5 Precursor satellite. The Sentinel-5 Precursor satellite was launched into low Earth orbit on 13 October 2017 with an equatorial crossing time of 13:30 local solar time (LST) and a $16 \mathrm{~d}$ orbit cycle. TROPOMI has a wide swath $(2600 \mathrm{~km}$ across track), enabling near-daily global coverage. The spatial resolution of the ground pixels is $7 \mathrm{~km}$ along track ${ }^{1}$ and $3.5-15 \mathrm{~km}$ across track $(3.5 \mathrm{~km}$ at nadir and $15 \mathrm{~km}$ at the edge of the swath). Of particular relevance here is the near-infrared band (725$775 \mathrm{~nm}$ ) that covers the far-red part of SIF emission and contains a number of solar absorption features in the solar irradiance (Fraunhofer lines), allowing for retrieval of SIF through the change in optical depth of Fraunhofer lines. Guanter et al. (2015) showed the potential for TROPOMI to retrieve SIF and Köhler et al. (2018) presented the first retrievals. Specifically, Köhler et al. (2018) used a 743-758 nm retrieval window that is devoid of atmospheric absorption features. TROPOMI has a spectral resolution of $\sim 0.4 \mathrm{~nm}$ and a signal-to-noise ratio of $\sim 2500$ in this retrieval window. The TROPOMI SIF retrieval uses a singular value decomposition to derive the spectral basis functions from TROPOMI data over vegetation-free areas (e.g., oceans, ice, and deserts).

One particularly attractive feature of space-borne SIF retrievals is the low sensitivity to atmospheric scattering by aerosols and clouds. Specifically, Frankenberg et al. (2012) showed that $80 \%$ of the emitted SIF could be retrieved in the presence of clouds with low-to-moderate optical thickness. As such, Köhler et al. (2018) filtered out pixels with cloud fractions larger than $80 \%$ based on Visible Infrared Imaging Radiometer Suite (VIIRS) observations; we use this same cloud filtering here. This weak sensitivity to clouds is in contrast to reflectance-based measures of vegetation (e.g., NDVI) that can only be made in clear-sky conditions, poten-

\footnotetext{
${ }^{1}$ Along-track resolution increased to $5.6 \mathrm{~km}$ in August 2019 (http://www.tropomi.eu/mission-status, last access: 2 January 2020).
}

tially inducing a clear-sky bias in reflectance-based vegetation indices.

Here, we apply one additional bias correction to the TROPOMI retrievals that was not included in Köhler et al. (2018). We find some mostly barren regions have systematically negative SIF values, which is non-physical. This bias is thought to be related to bright surfaces and is likely due to the choice of training data for the spectral basis functions. We are investigating ways to correct this globally. In the interim, we compute a spatiotemporal bias correction $b_{i, j, k}$ (where $i, j$ are the spatial coordinates and $k$ is the temporal coordinate) such that the mean SIF for a given location over a $30 \mathrm{~d}$ moving window is always positive. That is to say,

$b_{i, j, k}=\left\{\begin{array}{cc}\left|\bar{s}_{i, j, k}\right|, & \bar{s}_{i, j, k}<0 \\ 0, & 0 \leq \bar{s}_{i, j, k}\end{array}\right.$

where $\bar{s}_{i, j, k}$ is the 1 -month block average for the $k$ th day at location $i, j$. This still allows for negative SIF values due to variability and noise but will shift the mean SIF for a given $500 \mathrm{~m}$ grid cell to be positive. In practice, this bias correction is small, with $78 \%$ having no bias correction at all and $90 \%$ of the grid cells having a bias correction smaller than $0.1 \mathrm{~mW} \mathrm{~m}^{-2} \mathrm{sr}^{-1} \mathrm{~nm}^{-1}$. The bias correction primarily impacts desert regions in southeastern California (see Fig. S1 in the Supplement).

\subsection{Satellite-based vegetation indices from MODIS}

The MODerate Resolution Imaging Spectroradiometer (MODIS) is an imaging spectrometer on NASA's Terra and Aqua satellites. Terra was launched in 2000 and Aqua was launched in 2002; both are in Sun-synchronous orbits with 16 orbits per day. Terra and Aqua have equatorial crossing times at 10:30 and 12:00 LST, respectively. Schaaf et al. (2002) developed the nadir bidirectional reflectance distribution function-adjusted reflectance (NBAR) dataset, hereafter referred to as the MODIS NBAR dataset. MODIS data over a $16 \mathrm{~d}$ period from Terra and Aqua can be combined to build a $500 \mathrm{~m}$ composite: MCD43A4. Here, we use the MCD43A4.006 (v06) MODIS NBAR dataset to compute three MODIS vegetation indices at $500 \mathrm{~m}$ resolution. Specifically, we compute the NDVI, EVI, and near-infrared reflectance of vegetation index $\left(\mathrm{NIR}_{\mathrm{V}}\right)$ :

$$
\begin{aligned}
\mathrm{NDVI} & =\frac{\rho_{\mathrm{NIR}}-\rho_{\text {red }}}{\rho_{\mathrm{NIR}}+\rho_{\mathrm{red}}} \\
\mathrm{EVI} & =G \cdot \frac{\rho_{\mathrm{NIR}}-\rho_{\text {red }}}{\rho_{\mathrm{NIR}}+C_{1} \rho_{\text {red }}-C_{2} \rho_{\text {blue }}+L} \\
\mathrm{NIR}_{\mathrm{V}} & =\rho_{\mathrm{NIR}} \cdot \mathrm{NDVI},
\end{aligned}
$$

where $\rho_{\mathrm{NIR}}, \rho_{\text {red }}$, and $\rho_{\mathrm{Blue}}$ are the reflectances in their respective MODIS bands, and $G, C_{1}, C_{2}$, and $L$ are coefficients for the MODIS EVI algorithm $\left(L=1, C_{1}=6\right.$, and $C_{2}=7.5$, $G=2.5$ ). 


\subsection{GPP estimates from AmeriFlux eddy covariance sites}

AmeriFlux is a network of long-term eddy covariance sites that launched in 1996 (Baldocchi et al., 2001). These eddy covariance sites provide a direct measure of net ecosystem exchange (NEE; $\mathrm{CO}_{2}$ fluxes) (Baldocchi et al., 1988) and can be used to evaluate both bottom-up models and satellite proxies of carbon exchange. Disentangling the $\mathrm{CO}_{2}$ fluxes into GPP $\left(\mathrm{CO}_{2}\right.$ uptake $)$ and total ecosystem respiration $\left(R_{\text {eco }}\right.$; $\mathrm{CO}_{2}$ released) generally requires making assumptions about the temperature dependence of the respiration which can induce biases in the GPP estimate (Reichstein et al., 2005). Nevertheless, these eddy covariance sites provide the best estimate of site-level GPP across multiple ecosystems in California including croplands, wetlands, woody savannas, and grasslands. Here, we use data from 11 AmeriFlux sites across California (see Table 1) to evaluate the SIF retrievals from TROPOMI. NEE flux partitioning at these sites was performed using artificial neural networks from nighttime measurements to constrain $R_{\text {eco }}$ (Hemes et al., 2019).

\subsection{Comparison of TROPOMI SIF with MODIS vegetation indices}

Figure 2 shows a scatterplot comparison of TROPOMI SIF

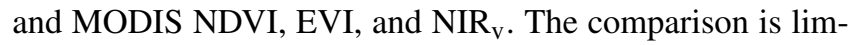
ited to coincident observations between March and August (MAMJJA) and excludes scenes that are predominantly barren or shrubland. A few features that immediately stand out are as follows:

1. There is a strong correspondence between EVI and $\mathrm{NIR}_{\mathrm{v}}$. We find a nearly linear relationship between these two indices $\left(r^{2}=0.98\right)$.

2. All three MODIS indices are well correlated with each other $\left(r^{2}>0.85\right)$. We do observe a weakly non-linear relationship between $\mathrm{NIR}_{\mathrm{V}}$ and EVI or NDVI (see the curvature in the $\mathrm{NIR}_{\mathrm{v}}$ row).

3. There is a weaker relationship between SIF and the vegetation indices. Previous work has argued that $\mathrm{NIR}_{\mathrm{V}}$ is strongly correlated with SIF (Badgley et al., 2017) and provides a new independent approach for estimating GPP (Badgley et al., 2019).

Of the three vegetation indices examined here, we find the strongest relationship between $\mathrm{NIR}_{\mathrm{v}}$ and SIF, but it only explains half of the variability on daily timescales $\left(r^{2}=0.52\right)$. The agreement improves at coarser temporal scales (annual $r^{2}=0.83-0.84$ and monthly $r^{2}=0.59 \pm 0.23$ ). It is important to note that the native spatial resolution of the TROPOMI observations is $3.5 \mathrm{~km}$ across track at nadir, whereas the MODIS observations are $500 \mathrm{~m}$ across track at nadir. As such, we are using all MODIS observations within a single TROPOMI scene. Comparison of four methods of down- scaling SIF with NIR $\mathrm{V}_{\mathrm{v}}$ yields coefficients of determination of $r^{2}=0.52-0.64$; see Fig. S2).

\section{Oversampling and spatial downscaling of TROPOMI data}

As mentioned above, the nominal spatial resolution of the ground pixels from TROPOMI is $3.5 \times 7 \mathrm{~km}^{2}$ at nadir. However, the wide swath from TROPOMI (2600 km across track) often results in multiple observations per day (see Fig. 3b). Additionally, the orientation of these swaths differs over the $16 \mathrm{~d}$ orbit cycle, allowing us to infer higher spatial resolution than the nominal spatial resolution. This idea has been widely used with the space-borne OMI instrument that preceded TROPOMI (see K. Sun et al., 2018, and references therein for a discussion of oversampling with OMI observations). However, the spatial resolution of TROPOMI is a factor of 15 finer than OMI $\left(3.5 \times 7 \mathrm{~km}^{2}\right.$ for TROPOMI and $14 \times 26 \mathrm{~km}^{2}$ for OMI, both at nadir). Oversampling with OMI often required years of observations (e.g., Zhu et al., 2014). The wide swath and dense spatial coverage of TROPOMI allow us to perform biweekly oversampling.

Figure 3 shows a schematic of how the oversampling is performed. Figure 3 a shows two hypothetical swaths from TROPOMI overlaid on a $500 \mathrm{~m}$ grid (same spatial resolution as the MODIS NBAR dataset). Areas where the swaths overlap allow us to partition the information down to a finer spatial scale. For example, the yellow pixel in swath B overlaps with all four pixels from swath A. As such, the signal from that pixel in swath B can be subdivided to finer spatial scales. Each unique shade of color would correspond to unique information in Fig. 3a. Figure 3b shows the sampling density of TROPOMI over California on a single day in June 2018; the dark blue region indicates where two TROPOMI swaths overlapped that day.

We find that, on average, each $500 \mathrm{~m}$ grid cell is within the bounds of $\sim 0.6$ TROPOMI scenes with a successful retrieval per day. By using biweekly oversampling (a moving $14 \mathrm{~d}$ window), we obtain approximately eight different swath orientations over a $14 \mathrm{~d}$ period for the oversampling. These eight swath orientations allow us to further refine our grid to follow the schematic shown in Fig. 3. It also means that the daily values presented here are representative of $14 \mathrm{~d}$ moving averages (centered about that day).

We can take the oversampling a step further by preweighting the SIF signal in a TROPOMI scene by the underlying vegetation fraction; we refer to this as "downscaling". That is to say, we assume the observed SIF from TROPOMI in a given scene likely originates from more vegetated regions within that scene. Here, we use a relative weighting for this downscaling:

$s_{i, j}=s^{\star} \frac{v_{i, j}}{\bar{v}}$, 
Table 1. AmeriFlux sites used in this study.

\begin{tabular}{|c|c|c|c|c|c|}
\hline Site ID & Site name & $\begin{array}{r}\text { Latitude } \\
\qquad\left({ }^{\circ} \mathrm{N}\right)\end{array}$ & $\begin{array}{r}\text { Longitude } \\
\left({ }^{\circ} \mathrm{W}\right)\end{array}$ & $\begin{array}{r}\text { Elevation } \\
\text { (ma.s.1.) }\end{array}$ & $\begin{array}{l}\text { Vegetation } \\
\text { type }^{\mathrm{a}}\end{array}$ \\
\hline US-Bi1 & Bouldin Island Alfalfa & 38.0992 & 121.4993 & -3 & $\mathrm{CRO}^{\mathrm{b}}$ \\
\hline US-Bi2 & Bouldin Island Corn & 38.1090 & 121.5350 & -5 & $\mathrm{CRO}^{\mathrm{b}}$ \\
\hline US-EDN & Eden Landing Ecological Reserve & 37.6156 & 122.1140 & 1 & $\mathrm{WET}^{\mathrm{c}}$ \\
\hline US-Myb & Mayberry Wetland & 38.0499 & 121.7650 & -4 & $\mathrm{WET}^{\mathrm{c}}$ \\
\hline US-Sne & Sherman Island Restored Wetland & 38.0369 & 121.7547 & -5 & GRA $^{\mathrm{d}}$ \\
\hline US-Ton & Tonzi Ranch & 38.4316 & 120.9660 & 177 & $\mathrm{WSA}^{\mathrm{e}}$ \\
\hline US-Tw1 & Twitchell Island West Pond & 38.1074 & 121.6469 & -9 & WET $^{\mathrm{c}}$ \\
\hline US-Tw3 & Twitchell Island Alfalfa & 38.1159 & 121.6467 & -9 & $\mathrm{CRO}^{\mathrm{b}}$ \\
\hline US-Tw4 & Twitchell Island East End & 38.1030 & 121.6414 & -5 & WET $^{\mathrm{c}}$ \\
\hline US-Tw5 & Twitchell Island East Pond & 38.1072 & 121.6426 & -5 & $\mathrm{WET}^{\mathrm{c}}$ \\
\hline US-Var & Vaira Ranch & 38.4133 & 120.9507 & 129 & $\mathrm{GRA}^{\mathrm{d}}$ \\
\hline
\end{tabular}

a Vegetation classification is based on the International Geosphere-Biosphere Programme (IGBP) classification scheme (Strahler et al., 1999). ${ }^{\mathrm{b}} \mathrm{CRO}$ (croplands) are lands covered with temporary crops followed by harvest and a bare soil period (e.g., single and multiple cropping systems). Note that perennial woody crops will be classified as the appropriate forest or shrub land cover type. ${ }^{c}$ WET (permanent wetlands) are lands with a permanent mixture of water and herbaceous or woody vegetation that cover extensive areas. The vegetation can be present in either saltwater, brackish water, or freshwater. ${ }^{\mathrm{d}}$ GRA (grasslands) are lands with herbaceous types of cover. Tree and shrub cover is less than $10 \%$. ${ }^{\mathrm{e}}$ WSA (woody savannas) are lands with herbaceous and other understory systems, and with forest canopy cover between $30 \%$ and $60 \%$. The forest cover height exceeds $2 \mathrm{~m}$.

where $s^{\star}$ is the retrieved SIF from TROPOMI for a single scene, $s_{i, j}$ is the SIF spatially downscaled to $500 \mathrm{~m}, v_{i, j}$ is the vegetation indices from MODIS that fall within the bounds of a single scene from TROPOMI (i.e., the gray boxes within a TROPOMI box in the left panel of Fig. 3), and $\bar{v}$ is the mean vegetation index over a given TROPOMI scene. Using Eq. (5) with $v=[1, \ldots, 1]$ returns the unweighted oversampling result. Following this, $s_{i, j}$ will naturally revert to oversampling in regions with homogeneous vegetation (as inferred by MODIS).

Figure 4 shows the 2018 annual mean SIF from TROPOMI from Köhler et al. (2018) at $0.05^{\circ} \times 0.05^{\circ}$ spatial resolution and California's seasonal cycle at weekly temporal resolution (non-bias corrected). The middle and bottom rows of Fig. 4 show the 2018 annual mean SIF and seasonal cycle using oversampling and spatially downscaled with $\mathrm{NIR}_{\mathrm{V}}$ from MODIS. All three show consistent largescale spatial patterns. We do, however, find significant differences between the results from Köhler et al. (2018) and the oversampling or downscaling method over the San Francisco Bay Area where the complex topography induces numerical artifacts such as high SIF values over water. We also point out that the Köhler et al. (2018) seasonal cycle is produced at weekly temporal frequency, whereas we produce daily estimates using a $14 \mathrm{~d}$ moving window. The oversampling and downscaling methods both yield consistent large-scale patterns and seasonal cycles (left panels in Fig. 4). The main impact of the MODIS-based local downscaling is a sharpening effect. This can be seen in the right column of Fig. 4 . Importantly, the gradients observed in the oversampled SIF are also present in the downscaled SIF. The choice of which MODIS vegetation index to use in the downscaling makes lit- tle difference, as the $r^{2}$ between the different downscaled SIF products ranges from 0.99 to 1.00 (see Fig. S2); hereafter, we use SIF downscaled with $\mathrm{NIR}_{\mathrm{V}}$ because, of the three vegetation indices, $\mathrm{NIR}_{\mathrm{v}}$ showed the strongest correlation to SIF (see Fig. 2). Again, we stress that the large-scale spatiotemporal patterns are conserved between the oversampling and downscaling methods, and the nuanced difference in processing allows for analysis at much finer spatiotemporal scales. That is to say that we are not inducing large-scale changes in the spatiotemporal patterns with these different methods of processing; those are robustly driven by the underlying SIF retrievals.

\section{Inferring GPP from SIF}

Previous work has shown strong empirical relationships between SIF and GPP at coarse spatial scales (e.g., Walther et al., 2016; Jeong et al., 2017; Parazoo et al., 2018; Zuromski et al., 2018; Y. Sun et al., 2018). Magney et al. (2019a) recently extended this SIF-GPP relationship by showing, in a conifer forest, how both SIF and GPP are regulated by seasonal changes in photoprotective pigments and how SIF is directly related to needle physiology.

Lee et al. (2013), Guanter et al. (2014), and Y. Sun et al. (2017) have previously argued for a linear relationship between SIF and GPP; this follows from a simple relational analysis. From Monteith theory (Monteith, 1972), we can write

$\mathrm{GPP}=\Phi_{\mathrm{CO}_{2}} \alpha I$,

where $\Phi_{\mathrm{CO}_{2}}$ is the light-use efficiency of $\mathrm{CO}_{2}$ assimilation, $I$ is the photosynthetically active radiation (PAR), and $\alpha$ is the 

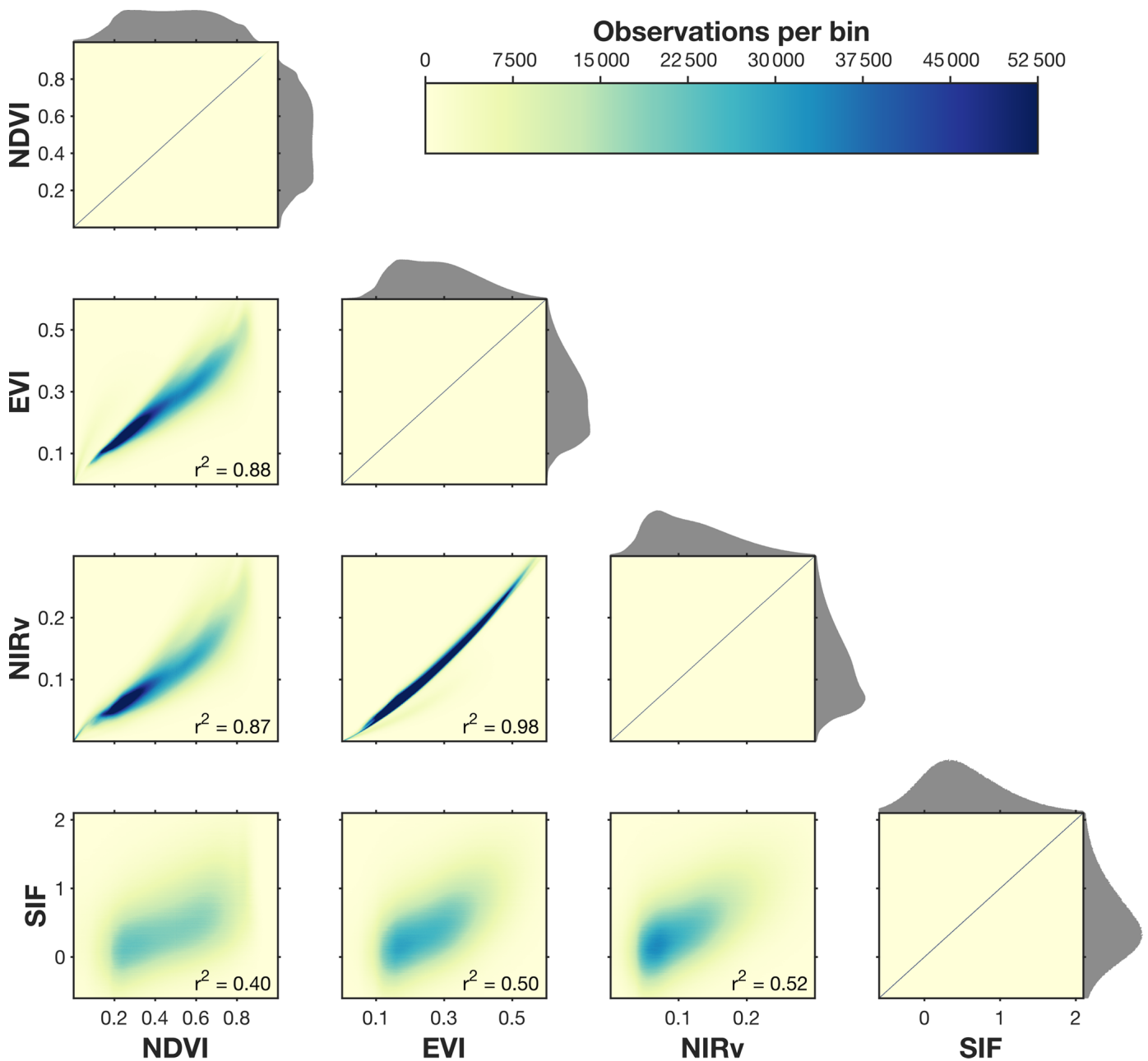

Figure 2. Comparison of MODIS vegetation indices and TROPOMI SIF from 2018 to 2019. Panels show a comparison of coincident measurements in both space and time of NDVI, EVI, NIR ${ }_{\mathrm{V}}$, and SIF. NDVI, EVI, and $\mathrm{NIR}_{\mathrm{V}}$ use the $500 \mathrm{~m}$ MODIS bidirectional reflectance distribution function (BRDF)-corrected reflectances, and SIF is from TROPOMI. Shading indicates the density of points. Data are filtered to only include measurements from March to August (MAMJJA). Data are further filtered to remove scenes that are more than $85 \%$ barren or shrubland as defined by the CropScape database. Gray histograms on the $x$ and $y$ axes show the distribution of values for a given set of data. NDVI, EVI, and $\mathrm{NIR}_{\mathrm{V}}$ are unitless, and SIF has units of $\mathrm{mW} \mathrm{m}^{-2} \mathrm{sr}^{-1} \mathrm{~nm}^{-1}$. Figure $\mathrm{S} 2$ in the Supplement shows the comparison including the SIF downscaled using local MODIS vegetation indices.

fractional absorbance of PAR. An analogous expression can be written for SIF (Lee et al., 2013):

$\mathrm{SIF}=\Phi_{F} \alpha \beta I$,

where $\Phi_{F}$ is the light-use efficiency of SIF and $\beta$ is the probability of SIF photons escaping the canopy. Rearranging yields

$\mathrm{GPP}=\frac{\Phi_{\mathrm{CO}_{2}}}{\beta \Phi_{F}} \mathrm{SIF}$

From Eq. (8), we can see that GPP should be proportional to SIF. However, there are likely differences in $\Phi_{\mathrm{CO}_{2}} /\left(\beta \Phi_{F}\right)$ between ecosystems. Notably, Yang et al. (2018) argued that SIF is more strongly correlated with the absorbed PAR $(\alpha I)$ than with GPP at subdaily timescales, which implicitly points to non-linearities in $\Phi_{\mathrm{CO}_{2}} /\left(\beta \Phi_{F}\right)$. $\beta$ will be a function of the canopy structure and likely differs between ecosystems, although some studies have argued that reflectance measurements could be used to infer $\beta$ (Yang and van der Tol, 2018; Zeng et al., 2019). Additionally, the ratio of $\Phi_{\mathrm{CO}_{2}}$ to $\Phi_{F}$ will likely be ecosystem specific due to, for example, differences in photosynthetic pathways $\left(C_{3}\right.$ versus $C_{4}$ plants; Liu et al., 2017). A number of studies have found the relationship between chlorophyll fluorescence and GPP to be non-linear at the leaf scale (e.g., Magney et al., 2017, 2019b), owing the increased linearity at the canopy scale to averaging SIF and GPP over many different leaf angles exposed to highly heterogenous light environments. 

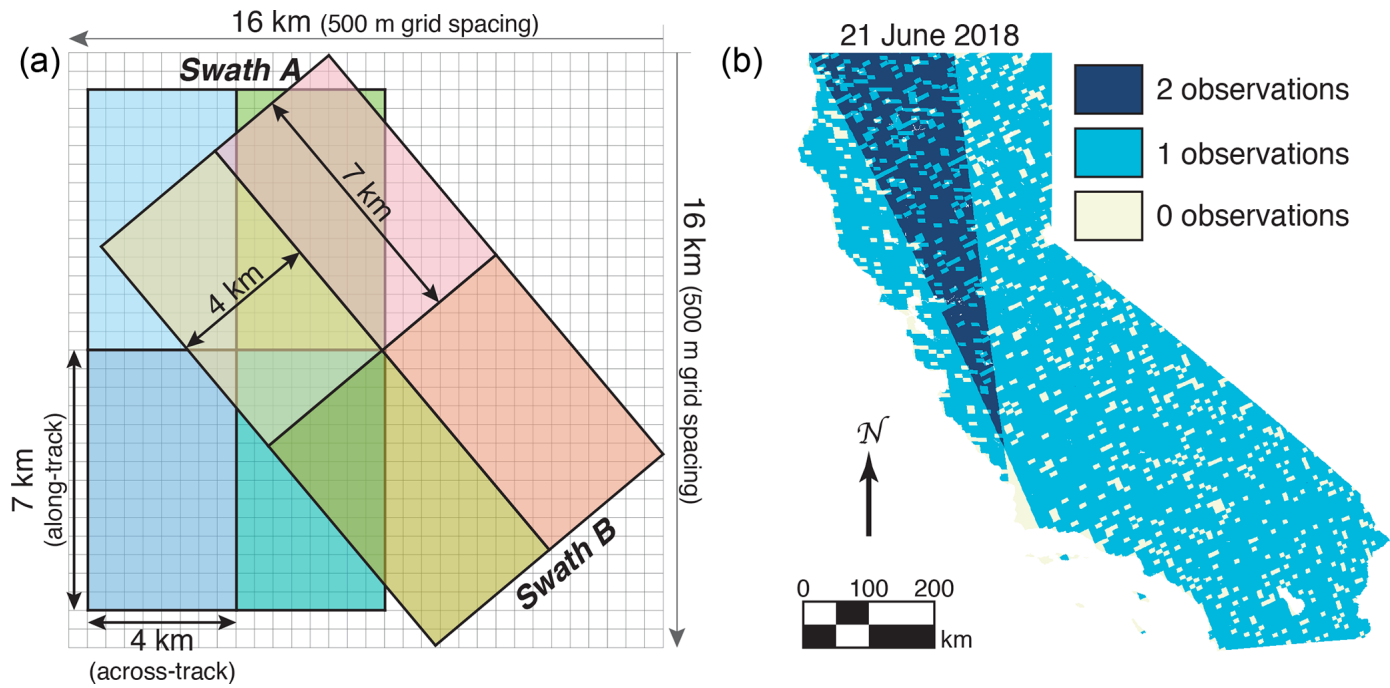

Figure 3. Oversampling schematic. Panel (a) shows the schematic for our oversampling. Gray grid has a grid spacing of $500 \mathrm{~m}$ (equivalent to the spatial resolution of the MODIS MCD43A4 product). TROPOMI ground pixels are $7 \mathrm{~km}$ along track and vary from $3.5 \mathrm{~km}$ (at nadir) to $15 \mathrm{~km}$ the across track. Schematic shows the spatial extent of eight hypothetical TROPOMI scenes from two swaths at $7 \times 4 \mathrm{~km}^{2}$; individual TROPOMI scenes are a different color. Swath B is rotated $40^{\circ}$ relative to swath A, resulting in overlapping pixels. Panel (b) shows the number of successful retrievals on 21 June 2018 over California plotted on a $500 \mathrm{~m}$ grid.

Figure 5 compares the TROPOMI SIF retrievals to observations from AmeriFlux sites across California (see Table 1 and Fig. 1 for the locations). The gray dots in Fig. 5 are all of the AmeriFlux GPP estimates and the black dots are those between 13:00 and 14:00 PST, similar to the TROPOMI overpass time (equatorial overpass time is 13:30 LST at nadir). This overpass time is fortuitous in that it generally coincides with the daily maximum in GPP at the AmeriFlux sites. The green dots are the actual TROPOMI SIF retrievals at that location that have the scene-specific relative weighting from

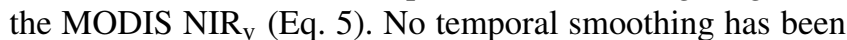
applied in Fig. 5. We find a strong correspondence between SIF and GPP across four different ecosystems. The top left panel shows that SIF clearly captures the onset of photosynthesis as well as the punctuated seasonal cycle of GPP in a corn field (US-Bi2) with $r^{2}=0.79$. We also observe the gradual increase in GPP and abrupt decline at a woody savanna site (US-Ton) and grassland site (US-Var) with $r^{2}=$ 0.40 and $r^{2}=0.59$, respectively. The relatively high variability in SIF at US-Ton and US-Var from July to December ( $1 \sigma$ spread of $0.33 \mathrm{~mW} \mathrm{~m}^{-2} \mathrm{sr}^{-1} \mathrm{~nm}^{-1}$ ) contrasts the low variability during the dormant period at US-Bi2 and is likely associated with bright surfaces (implying a higher retrieval uncertainty), quantifying the upper range of anticipatable noise. The bottom row of Fig. 5 shows a comparison of TROPOMI SIF with GPP from three different wetland sites on Twitchell Island in the Sacramento-San Joaquin River Delta; we generally find a strong correspondence between TROPOMI SIF and the three wetland sites $\left(r^{2}=0.42,0.42\right.$, and 0.30 for USTw1, US-Tw4, and US-Tw5). The inter-site differences in GPP within a single ecosystem are larger than the SIF-GPP differences, indicating some fine-scale heterogeneity that is likely not being captured here. In any case, the reasonable agreement with the GPP at the wetland sites is encouraging because standing water can often bias reflectance-based indices, particularly in the NIR (Gamon et al., 2013).

From this SIF-GPP comparison in Fig. 5, we infer a SIF-GPP scaling factor of $18.5 \pm 4.9$ $\left[\left(\mu \mathrm{mol} \mathrm{m} \mathrm{m}^{-2} \mathrm{~s}^{-1}\right)\left(\mathrm{mW} \mathrm{m}^{-2} \mathrm{sr}^{-1} \mathrm{~nm}^{-1}\right)^{-1}\right]$ across the six sites in Fig. 5 (range of scaling factors is 13-25; see Fig. S3). Our comparison of TROPOMI SIF with GPP from AmeriFlux sites in California indicates larger inter-ecosystem differences in the SIF-GPP relationship than intra-ecosystem differences, lending credence to this universal scaling factor. However, there are two important caveats: (1) we do not have an eddy covariance site in an evergreen forest, which is a major limitation, as much of California is dominated by evergreen forests, and (2) we are not directly measuring GPP with SIF. As such, we refer to this SIF-estimated GPP as

$\mathrm{GPP}^{*}:=18.5 \cdot \mathrm{SIF}$.

This single scaling from Eq. (9) seems to be a reasonable relation given the available information, with the caveat that there could be differences between ecosystems that are unaccounted for. To reiterate, there is a clear correspondence between the observed SIF and GPP estimated for the different AmeriFlux sites (see Fig. 5) but we have a limited number of AmeriFlux sites in California that do not cover all ecosystems. As such, we do not report GPP here and have included an asterisk to highlight the caveats with the relationship pre- 

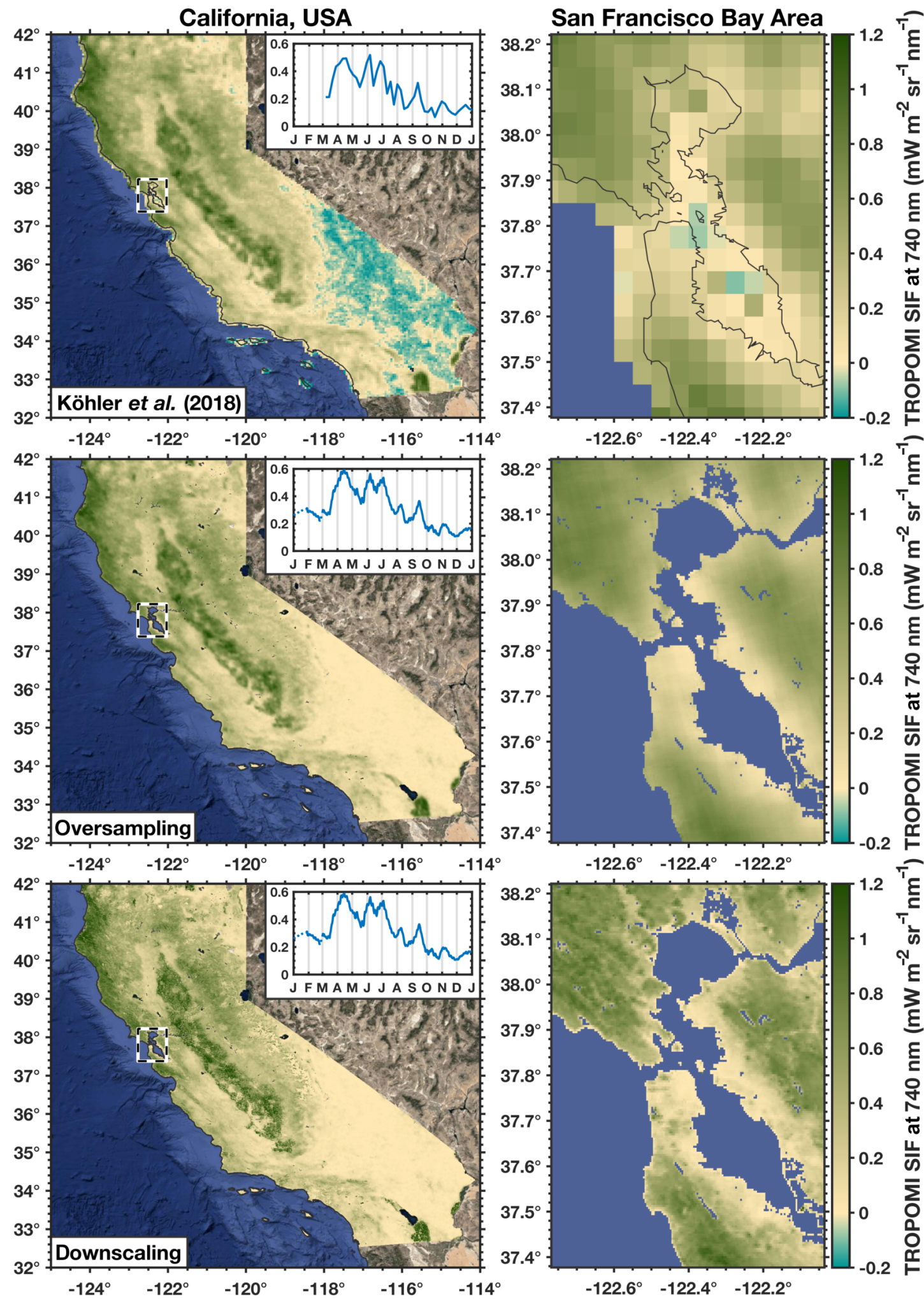

Figure 4. The 2018 annual mean photosynthesis. Top row shows the 2018 annual mean TROPOMI SIF from Köhler et al. (2018), and the inset shows the seasonal cycle $\left(0.05^{\circ} \times 0.05^{\circ}\right.$ spatial resolution and weekly temporal resolution, respectively). Middle row uses the same

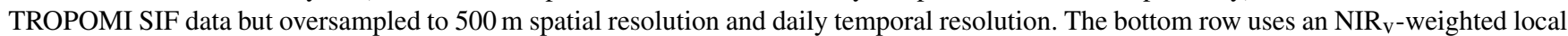
downscaling to $500 \mathrm{~m}$ spatial resolution. Left column shows all of California, USA, and right column shows the San Francisco Bay Area in detail. The dashed black line in the left column indicates the domain of the right column. 

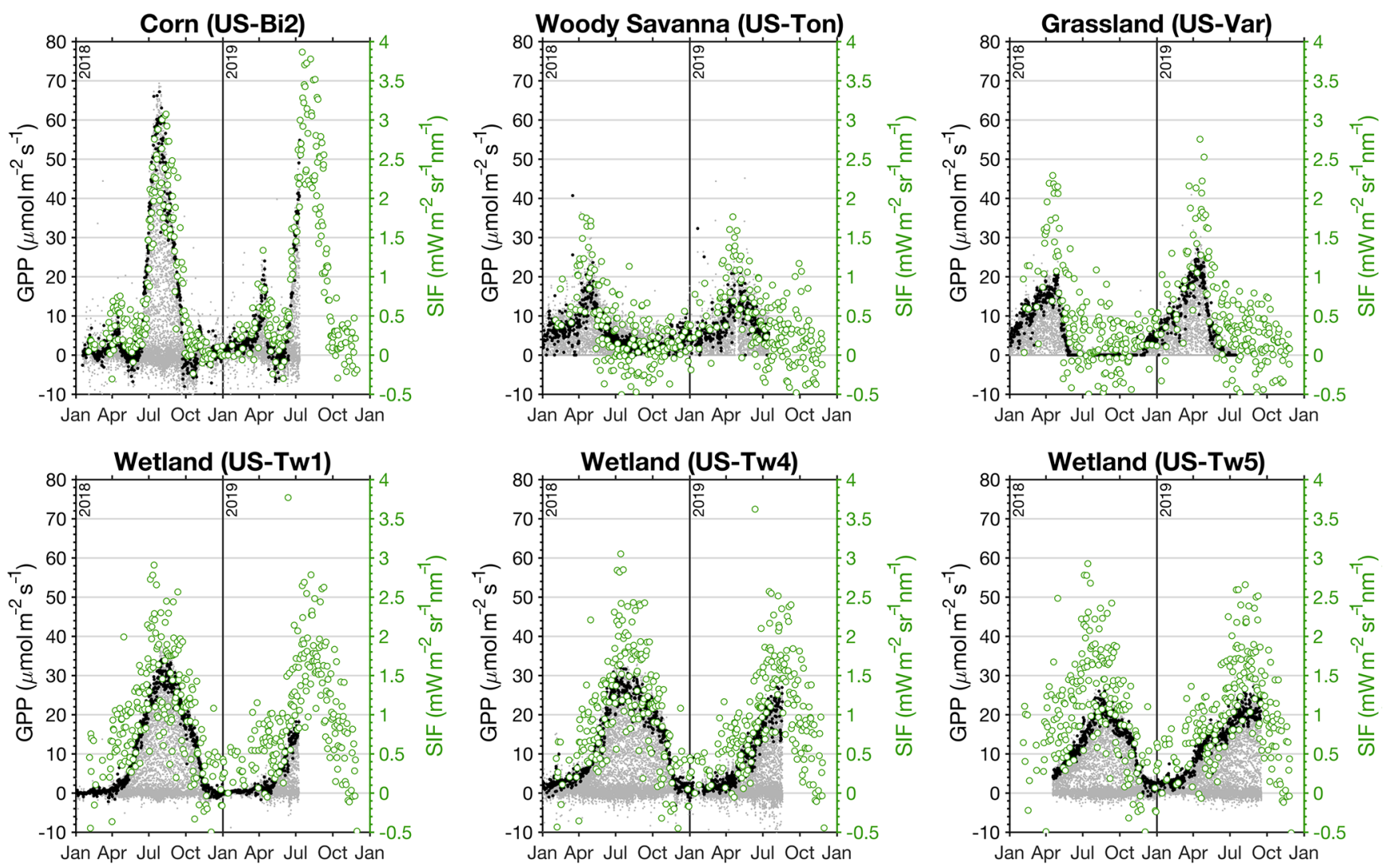

Figure 5. AmeriFlux GPP and TROPOMI SIF at six sites in California. Left axes (black) show GPP from AmeriFlux and right axes (green) show SIF values from TROPOMI that have been downscaled with $\mathrm{NIR}_{\mathrm{V}}$. Light gray dots show all of the GPP measurements from the AmeriFlux site and black dots indicate GPP measurements between 13:00 and 14:00 PST (TROPOMI equatorial overpass is 13:30 LST). Green circles show the TROPOMI SIF observations at the AmeriFlux sites after applying the scene-specific relative weighting from the MODIS $\mathrm{NIR}_{\mathrm{V}}$. The AmeriFlux sites used are Bouldin Island (US-Bi2; $38.1090^{\circ} \mathrm{N}, 121.5350^{\circ} \mathrm{W}$ ), Tonzi Ranch (US-Ton; $38.4316^{\circ} \mathrm{N}, 120.9660^{\circ} \mathrm{W}$ ), Vaira Ranch (US-Var; $38.4133^{\circ} \mathrm{N}, 120.9507^{\circ} \mathrm{W}$ ), Twitchell Island West Pond (US-Tw1; $38.1074^{\circ} \mathrm{N}, 121.6469^{\circ} \mathrm{W}$ ), Twitchell Island East End (US-Tw4; $38.1030^{\circ} \mathrm{N}, 121.6414^{\circ} \mathrm{W}$ ), and Twitchell Island East Pond (US-Tw5; $38.1072^{\circ} \mathrm{N}, 121.6426^{\circ} \mathrm{W}$ ). $\mathrm{CO}_{2}$ flux measurements and comparisons for other sites listed in Table 1 are shown in Figs. S3 and S4.

sented here. Future work to obtain a more robust SIF-GPP relationship covering more ecosystems is warranted.

\section{Timing and spatial patterns of photosynthesis in California}

Figure 6a shows the SIF-derived seasonal cycle of photosynthesis in California. One of the most prominent features is the apparent double peak in the seasonal cycle. This double peak is present in both 2018 and 2019 with similar timing of the maxima. The first peak occurs in April and the second peak occurs in June. Interestingly, the trough between these peaks occurs near the annual maximum in PAR (red line in Fig. 6d). This begs the following question: what is driving this double peak in the seasonality of California's photosynthesis?

We can use the CropScape database (see Fig. 1) to determine the ecosystems driving the spatiotemporal patterns in the TROPOMI SIF data, as it provides land cover clas- sifications across the state of California at $30 \mathrm{~m}$ spatial resolution. However, a notable limitation of the classifications from the CropScape data is the lack of discrimination for non-cropland areas. For example, grasslands and pastures are combined into a single land type that seems to also include regions that would typically be defined as oak savanna and chaparral. In lieu of a better sub-kilometer land cover dataset, we use the classifications from the CropScape database for this work.

Figure 6a shows a breakdown of the regions contributing to the statewide SIF signal based on the land cover data from the CropScape database. We find the California grasslands and pastures (a single classification that also includes chaparral and oak savanna) have a single peak that coincides with the first statewide peak in April; this is consistent with the seasonal cycle at California grassland sites in the AmeriFlux network (Fig. 5) that show a unimodal peak in the spring that ends in May. Figure 6e and $\mathrm{e}^{\prime}$ show the mean spatial pattern in April 2018 and 2019, respectively, where we see that 

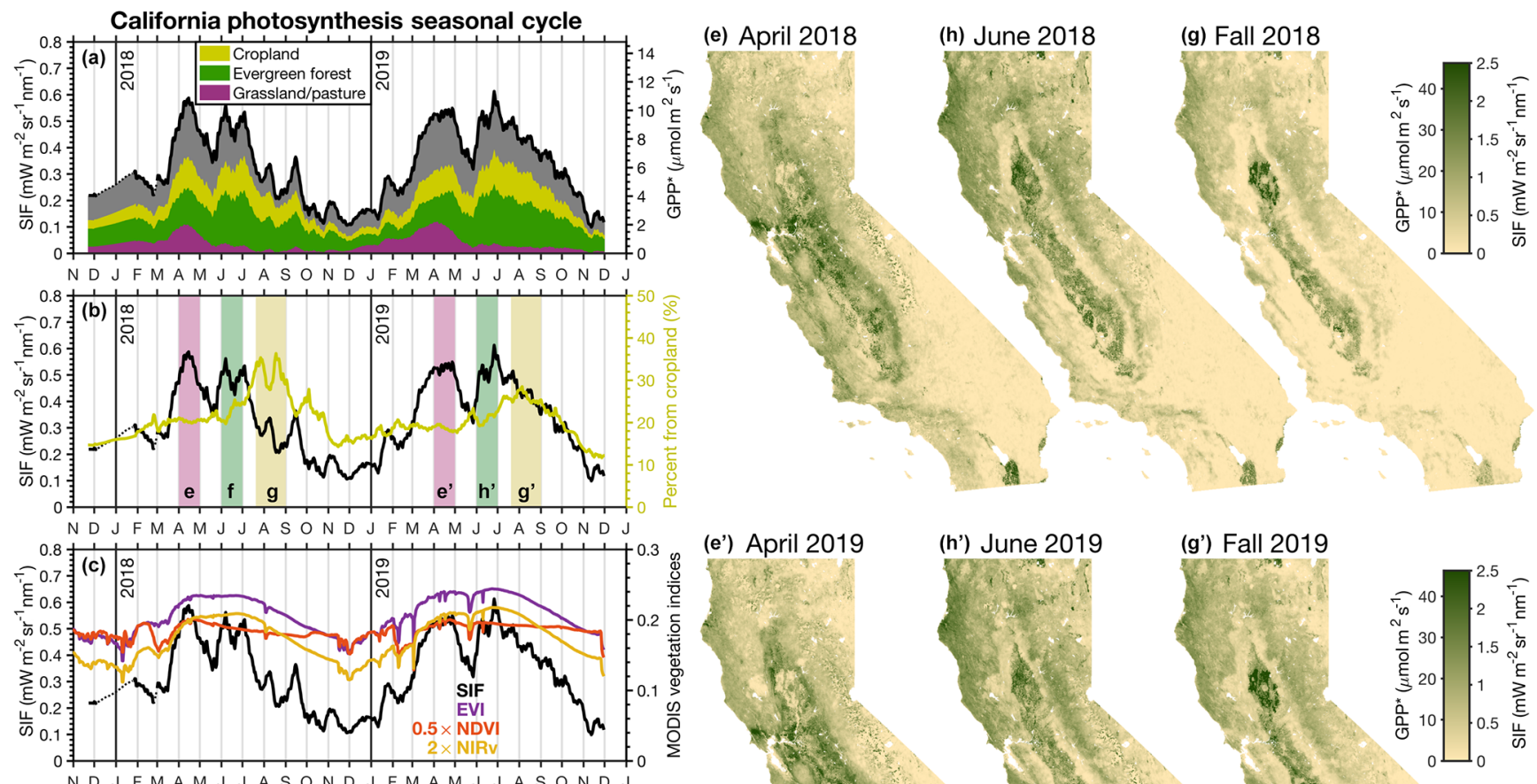

(e') April 2019

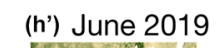

\section{(g') Fall 2019}

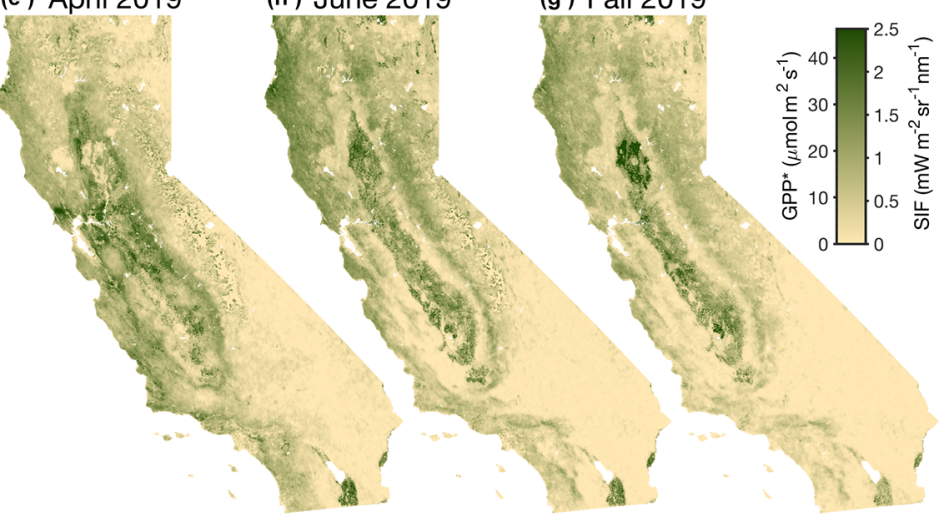

Figure 6. Seasonal cycle of photosynthesis in California. Panel (a) shows the statewide mean SIF (black line) at 13:30 PST from November 2017 to November 2019 broken down by the contributions coming from cropland (yellow), evergreen forests (green), grasslands or pastures (purple), and other (gray). Rice is included in cropland here. Land types are taken from the 2018 CropScape database shown in Fig. 1. The right axis shows the estimated GPP* based on comparison with AmeriFlux sites in California. Panel (b) shows the percentage of SIF coming from cropland (yellow). Vertical bars indicate the time periods with corresponding spatial plots in panels (e)-( $\left.\mathbf{g}^{\prime}\right)$. Panel (c) shows the vegetation indices (NDVI, EVI, and $\mathrm{NIR}_{\mathrm{V}}$ ) from MODIS over the same time period. Panel (d) shows clear-sky PAR over California at 13:00 PST (dashed red line), surface PAR estimated from the ERA-Interim reanalysis (thin red line), and cumulative precipitation over the water year from the Global Precipitation Measurement (GPM) satellite (blue). Panels (e)-( $\left.\mathbf{g}^{\prime}\right)$ show the spatial patterns of SIF for the time periods indicated in (b).

the April peak coincides with a statewide increase in SIF. There are a few pertinent hotspots in grasslands or pastures during this April peak. Notably, California's Central Valley and surrounding hills exhibit a strong photosynthesis signal in April. The valley to the east of Bodega Bay $\left(38.3^{\circ} \mathrm{N}\right.$, $122.9^{\circ} \mathrm{W}$ ) appears as a large hotspot in both 2018 and 2019. This region lies on transect B in Fig. 1, and the seasonal cycle is shown in more detail in Fig. 7.

The second peak in June shows a dominant contribution from evergreen forests (Fig. 6a). This can also be seen in the spatial patterns from Fig. of and $\mathrm{f}^{\prime}$ where the evergreen forests in Northern California exhibit a strong SIF signal. California's Central Valley can be clearly distinguished, as the surrounding hills have dried out (predominantly oak savanna and chaparral). The observed photosynthesis from the
Central Valley is maintained by heavily irrigated cropland throughout the valley.

The yellow line in Fig. 6b indicates the fraction of SIF in California that comes from cropland. We see the largest relative contribution occurring in the fall. However, this is primarily because all other ecosystems have gone dormant (see Fig. 6g) as opposed to an increase in photosynthetic activity from cropland. The only region that shows an increase in photosynthesis is the rice fields in the Sacramento Valley (the valley surrounding Sutter Buttes at $39.1^{\circ} \mathrm{N}, 121.5^{\circ} \mathrm{W}$ ) in Northern California. The rice fields show a SIF signal in excess of $2.5 \mathrm{~mW} \mathrm{~m}^{-2} \mathrm{sr}^{-1} \mathrm{~nm}^{-1}$ during the fall (GPP* in excess of $45 \mu \mathrm{mol} \mathrm{m}^{-2} \mathrm{~s}^{-1}$ ).

Both 2018 and 2019 show a double peak in the seasonal cycle; however, the onset of the grassland-driven peak dif- 

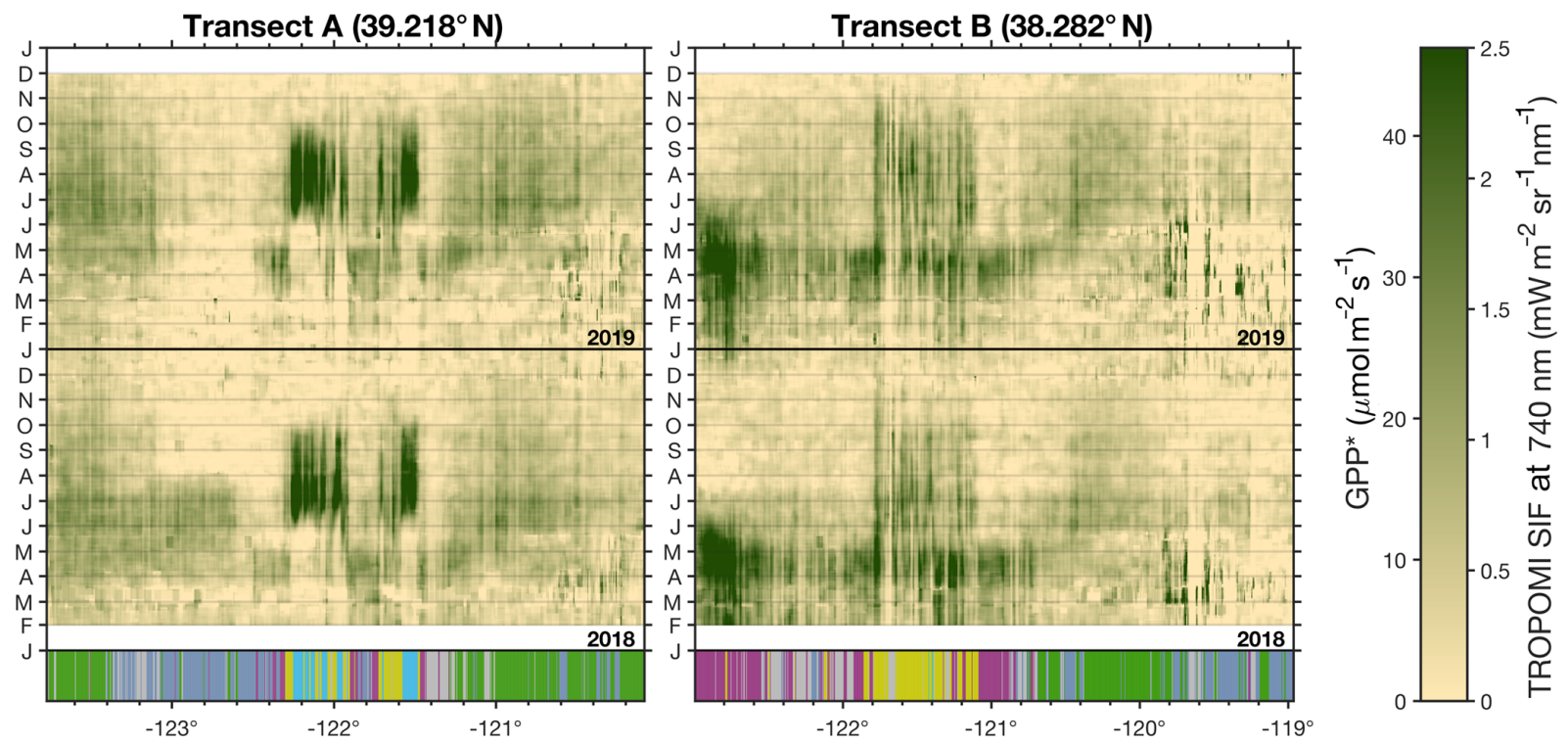

Figure 7. Hovmöller diagrams for three transects across California. Panels show Hovmöller diagrams from February 2018 to November 2019 for the two transects shown in Fig. 1. Bottom bar indicates the dominant land type with coloring from Fig. 1: green is evergreen forest, purple is grassland/pasture, cyan is rice, yellow is cropland (excluding rice), blue is shrubland, and gray is other.

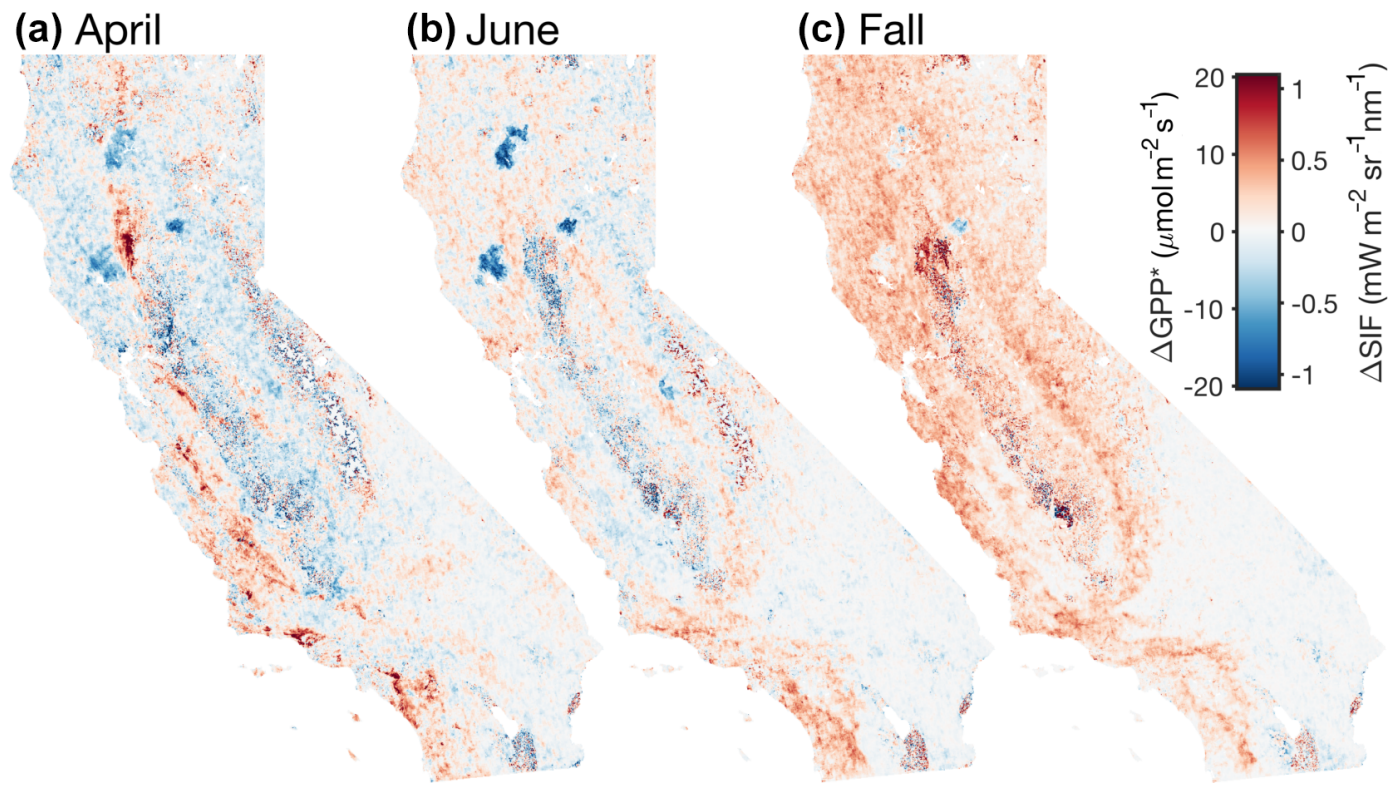

Figure 8. Difference between 2019 and 2018. Panel (a) shows the difference between the mean SIF in April 2019 and 2018. Panels (b) and (c) are the same as (a) but for June and fall (20 July-31 August), respectively. Red indicates higher SIF in 2019; blue indicates higher SIF in 2018.

fers substantially between the two years. This difference is likely driven by the increased precipitation in 2019 (blue line in Fig. 6d). There was $50 \%$ more precipitation in 2019 compared to 2018, and the precipitation occurred earlier in the water year. By mid-February 2019, there was more precipitation than the annual total from 2018. This early precipitation allowed for an earlier and longer growing season for the grasses. Figure 8 shows the difference in spatial patterns between 2019 and 2018. In general, we find reasonable consistency between the two years in April and June but substantial differences in the fall. We find a factor of 2 increase in statewide SIF between fall 2018 and 2019. This increase from 2018 to 2019 is exhibited across all ecosystems. This is, again, likely due to the increased precipitation in 2019 compared to 2018. The MODIS vegetation indices show negligible differences between fall 2019 and 2018 (see Figs. S6 
and S7). Most of the major differences in April and June are due to ecosystem disturbances such as fires. The 2018 Northern California fires are a striking example of that (three large negative anomalies in Fig. 8b); the impact of these fires is currently the focus of forthcoming work. An additional feature that stands out is the positive SIF anomaly in Southern California; this increase in 2019 is due to the low rainfall the previous year.

Interestingly, none of the MODIS vegetation indices (NDVI, EVI, or NIR ${ }_{\mathrm{V}}$ ) show this double peak in photosynthesis (Fig. 6c). The seasonal cycles from the three vegetation indices show a greening that starts in mid-winter (begins in December 2018) and increases roughly linearly to a peak in April. All three vegetation indices maintain that peak until July when they show a roughly linear decline through the fall. The seasonal cycle of the three MODIS vegetation indices bears a strong similarity to the clear-sky PAR seasonal cycle. This difference between SIF and the MODIS vegetation indices may be due to a clear-sky bias, as the reflectancebased vegetation indices (NDVI, EVI, and $\mathrm{NIR}_{\mathrm{V}}$ ) can only be made under clear-sky conditions, whereas SIF can be retrieved in the presence of some clouds and aerosols (Frankenberg et al., 2011b). This is inferred by the decline in PAR during May 2018 and May 2019 (Fig. 6d) that corresponds to a decline in SIF. This highlights one of the differences between SIF and the MODIS vegetation indices: the vegetation indices are reflectance-based products, whereas SIF is a fluorescence signal emitted during photosynthesis and is thus coupled to the radiation regime. This again gets back to the idea that SIF is measuring photosynthetic activity, whereas the MODIS indices are measuring photosynthetic capacity.

Several ecophysiological reasons could also explain the SIF detection of a double peak feature, whereas MODIS vegetation indices do not. Nearly $11 \%$ of the state of California consists of the California oak savanna (many in the foothills of coastal mountains and the Sierras; Tyler et al., 2006). Over the course of the season, these ecosystems operate as an evergreen ecosystem, whereby understory grass is photosynthetically active during the winter months, while trees (primarily oak species) reach extremely high values of maximum carboxylation capacity $\left(V_{\mathrm{cmax}}\right)$ during the spring when water is plentiful, and then retain their leaves throughout the summer in a highly photoprotective state (i.e., US-Ton; Xu and Baldocchi, 2003). Spatially, we observe increased SIF values in oak savanna as well as chaparral ecosystems (also present on coastal and Sierra foothills) in the early spring when available soil moisture is at a maximum (Xu and Baldocchi, 2004; Xu et al., 2004). As these ecosystems enter the hot, dry summers, increases in sustained non-photochemical quenching and decreases in photochemistry result in decreased fluorescence while still appearing "green" to MODIS vegetation indices. Meanwhile, snow is melting rapidly at higher elevations, making water available for many of the needleleaf evergreen species in the Sierras and coastal ranges; then the water resources become depleted and temperatures cool, prompting these evergreen species to go back into a photoprotective state, resulting in a short, photosynthetically active growing season that has been shown to be more well characterized by SIF from GOME-2 than MODIS NDVI and EVI (Zuromski et al., 2018). Future work comparing SIF and MODIS indices with measured PAR at AmeriFlux sites would be useful in further evaluating the role of radiation and physiology in the double peak feature.

Figure 7 shows a Hovmöller diagram for two transects across Northern California (see Fig. 1 for the location of the transects). Transect A in Fig. 7 shows the short but strong SIF signal from the rice fields. The timing of the SIF signal from the rice fields agrees with the growing cycle for rice in California. Rice in the Sacramento Valley is typically planted in mid-to-late May; the fields are then flooded and harvested in mid-to-late September (University of California at Davis, 2018). This observation of the rice fields is encouraging because we are observing photosynthesis in the presence of standing water, which can often bias reflectancebased indices in the NIR (Gamon et al., 2013). In both 2018 and 2019, we observe the onset of photosynthesis at the rice fields in the first few days of June and a rapid decline at the end of September. Transect B begins in the valley to the east of Bodega Bay (location of the grassland hotspot) and crosses the Central Valley. This grassland hotspot is present from April through May of both 2018 and 2019. The valley near Bodega Bay is dominated by pastures; however, it is currently unclear why this particular region exhibits a stronger SIF signal than other pastures in California. The persistent strong signal in 2018 and 2019 might make it an interesting site for study with an eddy covariance site in the future.

\section{Dominant "modes" of variability in California's photosynthesis}

Section 5 discussed the spatiotemporal patterns for different regions and ecosystems; here, we present an alternative method of characterizing the dominant modes of spatiotemporal variability in photosynthesis using EOFs and their associated principal components (PCs). EOFs are a matrix factorization that are commonly used to identify structure in a spatial dataset and yield a finite number of modes. These modes compactly represent the data and are often interpreted as physical modes of the system.

Figure 9 shows the first two EOFs and their associated PCs for the TROPOMI SIF data over California; the corresponding eigenvalue spectrum can be seen in Fig. S5. The first two EOFs corroborate the findings from Sect. 5 and, taken together, explain $84 \%$ of the variability in the TROPOMI SIF data:

- EOF 1: the mean signal and

- EOF 2: the double peak. 


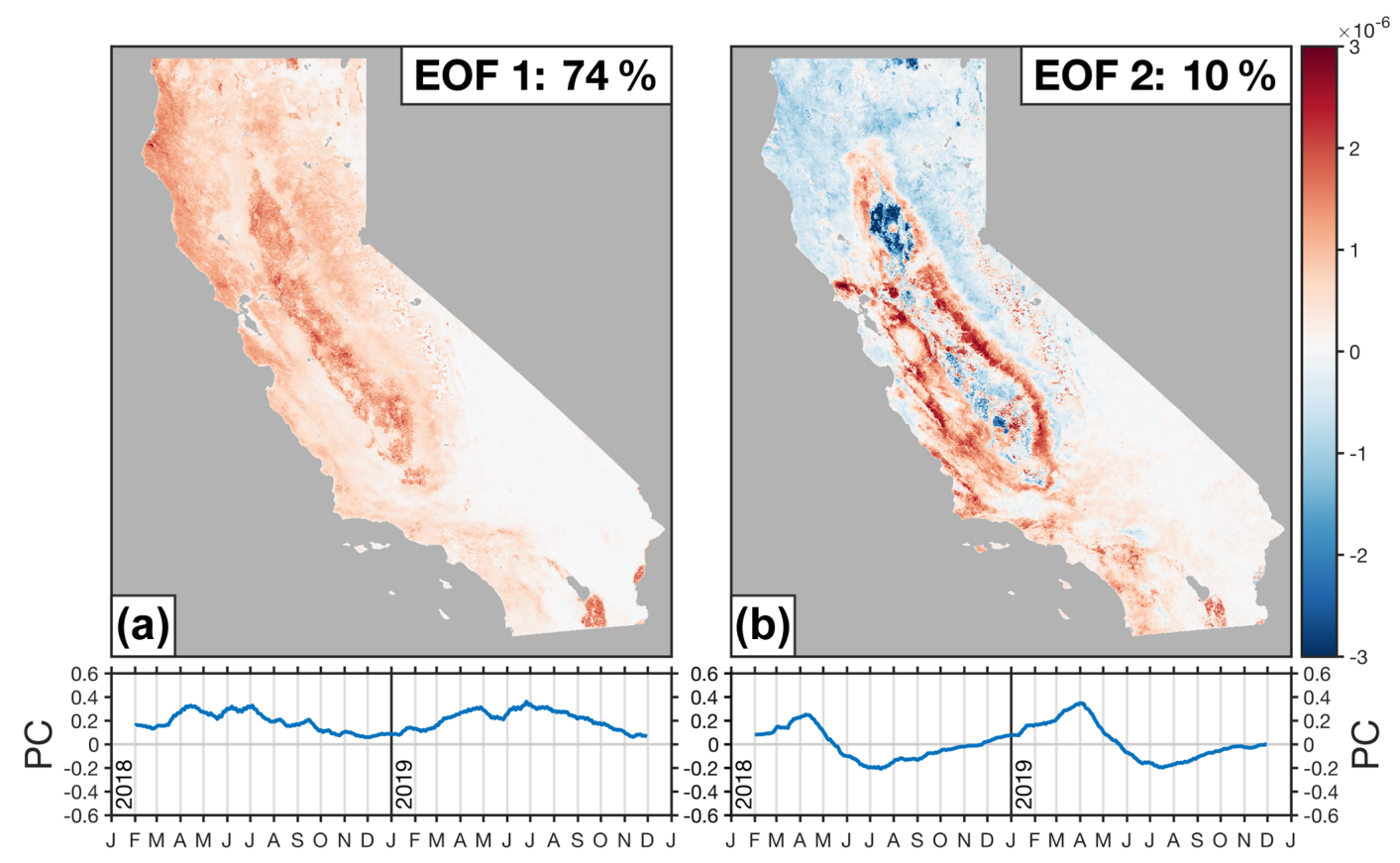

Figure 9. EOFs and PCs for TROPOMI SIF over California. Panels show the first two EOFs and PCs. EOFs are unit length (sum of the squares is equal to 1) and computed using unnormalized SIF spatially downscaled with $\mathrm{NIR}_{\mathrm{V}}$. Time series show the corresponding PC (blue line) from February 2018 to November 2019. The length of the PC is equal to the corresponding eigenvalue and has units of mW m $\mathrm{m} \mathrm{sr}^{-1} \mathrm{~nm}^{-1}$. The text in the figure lists the percent of variance explained by that EOF. Figure S5 shows the corresponding eigenvalue spectrum for the TROPOMI SIF data over California.

The first EOF (Fig. 9a) represents the mean signal and explains $74 \%$ of the variability in the TROPOMI SIF data. From the spatial pattern, we can see that it includes most of the biomass in California and is strongly correlated to the statewide mean SIF: $r^{2}=0.99$. The associated principal component bears a strong similarity to the statewide mean SIF seasonal cycle (Fig. 6a). This finding is not entirely surprising because we are using unnormalized SIF data for the matrix factorization. This means that the most important mode of variability is the mean signal and that the following EOFs are anomalies relative to the mean signal.

The second EOF (Fig. 9b) represents the double peak in the timing of California's photosynthesis. This EOF combines the signal from the grasslands (positive phase of EOF 2) and the evergreen forests (negative phase of EOF 2). We find EOF 2 to be positively correlated with the grassland fraction from the CropScape database $(r=0.55)$ and negatively correlated with the evergreen forests $(r=-0.37)$. There is also a negative correlation with the rice fields $(r=$ -0.32). The associated principle component serves to amplify the seasonal cycle from EOF 1 in grasslands during April and amplify the forest peak in June. This is because the red region (grasslands) in Fig. 9b will contribute a positive anomaly in April and a negative anomaly in June. Conversely, the blue region (evergreen forests and rice) will contribute a negative anomaly in April and a positive anomaly in June. This EOF arises because the grasslands and forests are both spatially separated and out of phase with each other, allowing the matrix factorization to place them into a single EOF that represents the processes driving the double peak in the timing of California's photosynthesis.

It should be noted that the EOF patterns found here are unlikely to be true "physical modes" (see, for example, Monahan et al., 2009). That is to say, we would not necessarily expect the response to a perturbation to follow patterns shown in Fig. 9. EOF 2 is a good example of this because it seems unlikely that the grasslands and forests will exhibit opposing responses to a forcing. Grasslands and forests are combined into a single EOF simply because there is little loss of information by combining them due to the spatial separation and phase offset. This is not to argue against the utility of EOFs. EOFs are a useful method for identifying structure in geophysical datasets, as evidenced here by their identification of the double peak in the timing of California's photosynthesis.

\section{Conclusions}

We present an oversampling and downscaling method to produce daily estimates of SIF, a proxy for photosynthetic activity, at $500 \mathrm{~m}$ spatial resolution from TROPOMI. To our knowledge, this is the highest spatial resolution SIF dataset from satellite measurements. We find a double peak in the seasonality of photosynthesis in California during 2018 and 2019, a feature that is not present in the MODIS vegetation 
indices (NDVI, EVI, or $\mathrm{NIR}_{\mathrm{v}}$ ). Analysis of the spatial and temporal patterns of the SIF data indicates that the double peak is due to two ecosystems that are out of phase with each other: woody grasslands (e.g., grasslands, chaparral, and oak savanna) and evergreen forests.

Our work applies methods developed for previous satellite retrievals (oversampling) and uses estimates of subgrid-scale vegetation (downscaling) to produce daily $500 \mathrm{~m}$ spatial resolution SIF from TROPOMI over California. We use a $14 \mathrm{~d}$ moving window to produce this estimate. The oversampling method results in a smooth spatial field and removes artifacts due to complex topography and the wide TROPOMI swath. The downscaling method further refines the high-resolution spatial patterns by bringing in a priori information on the subgrid vegetation patterns. The oversampling and downscaling methods do not alter the large-scale spatiotemporal patterns, as they conserve the SIF signal over a single scene.

TROPOMI SIF data and MODIS vegetation indices are reasonably consistent at annual timescales over California but show weaker relationships at daily and monthly timescales. This implies that TROPOMI SIF is providing some information that is distinct from the MODIS vegetation indices. TROPOMI SIF data show a strong correspondence with half-hourly estimates of GPP at multiple AmeriFlux sites across different ecosystems including cropland, grassland, savanna, and wetlands. We find a linear relationship between SIF and GPP that is largely invariant across ecosystems with an intercept that is not significantly different from zero. As such, we use SIF as an estimate of GPP* with the caveat that some ecosystems are not represented in our California analysis.

The double peak in the seasonality of California's photosynthesis observed by TROPOMI SIF is due to two ecosystems that are out of phase with each other: grasses show a maximum in April and evergreen forests peak in June. An EOF analysis corroborates the phase offset and spatial patterns driving the double peak. The EOF analysis also indicates that two spatiotemporal patterns explain $84 \%$ of the variability in the TROPOMI SIF data.

The results shown here are promising for obtaining global near-daily GPP at sub-kilometer spatial scales using satellite measurements. This, in turn, may prove helpful in addressing long-standing questions regarding the mechanisms and locations driving carbon uptake in the Northern Hemisphere. It would also allow us to monitor climate change impacts on vulnerable ecosystems at local to global scales.

Data availability. Data are available at https://doi.org/10.22002/ d1.1327 (Turner et al., 2019).

Supplement. The supplement related to this article is available online at: https://doi.org/10.5194/bg-17-405-2020-supplement.
Author contributions. AJT designed the research and conceived the methods. PK performed the satellite retrievals. AJT, PK, TSM, CF, IF, and RCC analyzed data. AJT wrote the paper; PK, TSM, CF, IF, and RCC provided comments on the paper.

Competing interests. The authors declare that they have no conflict of interest.

Acknowledgements. Alexander J. Turner is supported as a Miller Fellow with the Miller Institute for Basic Research in Science at UC Berkeley. Ronald C. Cohen acknowledges support from the TEMPO project SV3-83019. Philipp Köhler and Christian Frankenberg are funded by the Earth Science US participating investigator (grant no. NNX15AH95G). This research used the Savio computational cluster resource provided by the Berkeley Research Computing program at the University of California, Berkeley (supported by the UC Berkeley Chancellor, Vice Chancellor for Research, and Chief Information Officer). This research also used resources from the National Energy Research Scientific Computing Center, which is supported by the Office of Science of the US Department of Energy under contract no. DE-AC02-05CH11231. TROPOMI SIF and MODIS NBAR data are publicly available at ftp://fluo.gps.caltech. edu/data/tropomi/ (last access: 2 January 2020) and https://e4ft101. cr.usgs.gov/MOTA/MCD43A4.006/ (last access: 2 January 2020), respectively. Funding for AmeriFlux data resources was provided by the US Department of Energy's Office of Science. We would like to thank Dennis Baldocchi (UC Berkeley) for sharing the AmeriFlux data and for providing extensive feedback on the work. Finally, we are extremely grateful to the team that has realized the TROPOMI instrument, consisting of the partnership between Airbus Defence and Space, KNMI, SRON, and TNO, commissioned by NSO and ESA.

Financial support. This research has been supported by the Adolph C. and Mary Sprague Miller Institute for Basic Research in Science at the University of California Berkeley, the NASA TEMPO project (grant no. SV3-8019), and the NASA Earth Science participating investigator (grant no. NNX15AH95G).

Review statement. This paper was edited by Martin De Kauwe and reviewed by Luis Guanter and one anonymous referee.

\section{References}

Anav, A., Friedlingstein, P., Beer, C., Ciais, P., Harper, A., Jones, C., Murray-Tortarolo, G., Papale, D., Parazoo, N. C., Peylin, P., Piao, S., Sitch, S., Viovy, N., Wiltshire, A., and Zhao, M.: Spatiotemporal patterns of terrestrial gross primary production: A review, Rev. Geophys., 53, 785-818, https://doi.org/10.1002/2015rg000483, 2015.

Badgley, G., Field, C. B., and Berry, J. A.: Canopy near-infrared reflectance and terrestrial photosynthesis, Sci. Adv., 3, e1602244, https://doi.org/10.1126/sciadv.1602244, 2017. 
Badgley, G., Anderegg, L. D. L., Berry, J. A., and Field, C. B.: Terrestrial Gross Primary Production: Using NIRV to Scale from Site to Globe, Glob. Change Biol., 25, 3731-3740, https://doi.org/10.1111/gcb.14729, 2019.

Baker, N. R.: Chlorophyll fluorescence: a probe of photosynthesis in vivo, Annu. Rev. Plant Biol., 59, 89-113, https://doi.org/10.1146/annurev.arplant.59.032607.092759, 2008.

Baldocchi, D., Falge, E., Gu, L., Olson, R., Hollinger, D., Running, S., Anthoni, P., Bernhofer, C., Davis, K., Evans, R., Fuentes, J., Goldstein, A., Katul, G., Law, B., Lee, X., Malhi, Y., Meyers, T., Munger, W., Oechel, W., Paw, K. T., Pilegaard, K., Schmid, H. P., Valentini, R., Verma, S., Vesala, T., Wilson, K., and Wofsy, S.: FLUXNET: A New Tool to Study the Temporal and Spatial Variability of Ecosystem-Scale Carbon Dioxide, Water Vapor, and Energy Flux Densities, B. Am. Meteorol. Soc., 82, 2415-2434, https://doi.org/10.1175/15200477(2001)082<2415:fantts>2.3.co;2, 2001.

Baldocchi, D. D., Hicks, B. B., and Meyers, T. P.: Measuring Biosphere-Atmosphere Exchanges of Biologically Related Gases with Micrometeorological Methods, Ecology, 69, 13311340, https://doi.org/10.2307/1941631, 1988.

Ballantyne, A. P., Alden, C. B., Miller, J. B., Tans, P. P., and White, J. W.: Increase in observed net carbon dioxide uptake by land and oceans during the past 50 years, Nature, 488, 70-72, https://doi.org/10.1038/nature11299, 2012.

Ciais, P., Tan, J., Wang, X., Roedenbeck, C., Chevallier, F., Piao, S. L., Moriarty, R., Broquet, G., Le Quere, C., Canadell, J. G., Peng, S., Poulter, B., Liu, Z., and Tans, P.: Five decades of northern land carbon uptake revealed by the interhemispheric $\mathrm{CO}_{2}$ gradient, Nature, 568, 221-225, https://doi.org/10.1038/s41586019-1078-6, 2019.

Drusch, M., Moreno, J., Del Bello, U., Franco, R., Goulas, Y., Huth, A., Kraft, S., Middleton, E. M., Miglietta, F., Mohammed, G., Nedbal, L., Rascher, U., Schuttemeyer, D., and Verhoef, W.: The FLuorescence EXplorer Mission Concept-ESA's Earth Explorer 8, IEEE T. Geosci. Remote Sens., 55, 1273-1284, https://doi.org/10.1109/tgrs.2016.2621820, 2017.

Frankenberg, C., Butz, A., and Toon, G. C.: Disentangling chlorophyll fluorescence from atmospheric scattering effects in $\mathrm{O}_{2}$ A-band spectra of reflected sun-light, Geophys. Res. Lett., 38, L03801, https://doi.org/10.1029/2010gl045896, 2011a.

Frankenberg, C., Fisher, J. B., Worden, J., Badgley, G., Saatchi, S. S., Lee, J.-E., Toon, G. C., Butz, A., Jung, M., Kuze, A., and Yokota, T.: New global observations of the terrestrial carbon cycle from GOSAT: Patterns of plant fluorescence with gross primary productivity, Geophys. Res. Lett., 38, L17706, https://doi.org/10.1029/2011g1048738, 2011b.

Frankenberg, C., O’Dell, C., Guanter, L., and McDuffie, J.: Remote sensing of near-infrared chlorophyll fluorescence from space in scattering atmospheres: implications for its retrieval and interferences with atmospheric $\mathrm{CO}_{2}$ retrievals, Atmos. Meas. Tech., 5, 2081-2094, https://doi.org/10.5194/amt-5-2081-2012, 2012.

Frankenberg, C., O’Dell, C., Berry, J., Guanter, L., Joiner, J., Köhler, P., Pollock, R., and Taylor, T. E.: Prospects for chlorophyll fluorescence remote sensing from the Orbiting Carbon Observatory-2, Remote Sens. Environ., 147, 1-12, https://doi.org/10.1016/j.rse.2014.02.007, 2014.
Gamon, J. A., Huemmrich, K. F., Stone, R. S., and Tweedie, C. E.: Spatial and temporal variation in primary productivity (NDVI) of coastal Alaskan tundra: Decreased vegetation growth following earlier snowmelt, Remote Sens. Environ., 129, 144-153, https://doi.org/10.1016/j.rse.2012.10.030, 2013.

Guanter, L., Frankenberg, C., Dudhia, A., Lewis, P. E., GomezDans, J., Kuze, A., Suto, H., and Grainger, R. G.: Retrieval and global assessment of terrestrial chlorophyll fluorescence from GOSAT space measurements, Remote Sens. Environ., 121, 236251, https://doi.org/10.1016/j.rse.2012.02.006, 2012.

Guanter, L., Zhang, Y., Jung, M., Joiner, J., Voigt, M., Berry, J. A., Frankenberg, C., Huete, A. R., Zarco-Tejada, P., Lee, J. E., Moran, M. S., Ponce-Campos, G., Beer, C., CampsValls, G., Buchmann, N., Gianelle, D., Klumpp, K., Cescatti, A., Baker, J. M., and Griffis, T. J.: Global and timeresolved monitoring of crop photosynthesis with chlorophyll fluorescence, P. Natl. Acad. Sci. USA, 111, E1327-E1333, https://doi.org/10.1073/pnas.1320008111, 2014.

Guanter, L., Aben, I., Tol, P., Krijger, J. M., Hollstein, A., Köhler, P., Damm, A., Joiner, J., Frankenberg, C., and Landgraf, J.: Potential of the TROPOspheric Monitoring Instrument (TROPOMI) onboard the Sentinel-5 Precursor for the monitoring of terrestrial chlorophyll fluorescence, Atmos. Meas. Tech., 8, 1337-1352, https://doi.org/10.5194/amt-8-1337-2015, 2015.

Hemes, K. S., Chamberlain, S. D., Eichelmann, E., Anthony, T., Valach, A., Kasak, K., Szutu, D., Verfaillie, J., Silver, W. L., and Baldocchi, D. D.: Assessing the carbon and climate benefit of restoring degraded agricultural peat soils to managed wetlands, Agr. Forest Meteorol., 268, 202-214, https://doi.org/10.1016/j.agrformet.2019.01.017, 2019.

IPCC: Climate Change 2013: The Physical Science Basis. Contribution of Working Group I to the Fifth Assessment Report of the Intergovernmental Panel on Climate Change, Tech. rep., IPCC, Cambridge University Press, New York, NY, USA, 2013.

Jeong, S.-J., Schimel, D., Frankenberg, C., Drewry, D. T., Fisher, J. B., Verma, M., Berry, J. A., Lee, J.-E., and Joiner, J.: Application of satellite solar-induced chlorophyll fluorescence to understanding large-scale variations in vegetation phenology and function over northern high latitude forests, Remote Sens. Environ., 190, 178-187, https://doi.org/10.1016/j.rse.2016.11.021, 2017.

Joiner, J., Yoshida, Y., Vasilkov, A. P., Yoshida, Y., Corp, L. A., and Middleton, E. M.: First observations of global and seasonal terrestrial chlorophyll fluorescence from space, Biogeosciences, 8, 637-651, https://doi.org/10.5194/bg-8-637-2011, 2011.

Joiner, J., Yoshida, Y., Vasilkov, A. P., Middleton, E. M., Campbell, P. K. E., Yoshida, Y., Kuze, A., and Corp, L. A.: Filling-in of near-infrared solar lines by terrestrial fluorescence and other geophysical effects: simulations and space-based observations from SCIAMACHY and GOSAT, Atmos. Meas. Tech., 5, 809-829, https://doi.org/10.5194/amt-5-809-2012, 2012.

Joiner, J., Guanter, L., Lindstrot, R., Voigt, M., Vasilkov, A. P., Middleton, E. M., Huemmrich, K. F., Yoshida, Y., and Frankenberg, C.: Global monitoring of terrestrial chlorophyll fluorescence from moderate-spectral-resolution near-infrared satellite measurements: methodology, simulations, and application to GOME-2, Atmos. Meas. Tech., 6, 2803-2823, https://doi.org/10.5194/amt-6-2803-2013, 2013. 
Joiner, J., Yoshida, Y., Vasilkov, A. P., Schaefer, K., Jung, M., Guanter, L., Zhang, Y., Garrity, S., Middleton, E. M., Huemmrich, K. F., Gu, L., and Belelli Marchesini, L.: The seasonal cycle of satellite chlorophyll fluorescence observations and its relationship to vegetation phenology and ecosystem atmosphere carbon exchange, Remote Sens. Environ., 152, 375-391, https://doi.org/10.1016/j.rse.2014.06.022, 2014.

Joiner, J., Yoshida, Y., Guanter, L., and Middleton, E. M.: New methods for the retrieval of chlorophyll red fluorescence from hyperspectral satellite instruments: simulations and application to GOME-2 and SCIAMACHY, Atmos. Meas. Tech., 9, 39393967, https://doi.org/10.5194/amt-9-3939-2016, 2016.

Köhler, P., Guanter, L., and Joiner, J.: A linear method for the retrieval of sun-induced chlorophyll fluorescence from GOME-2 and SCIAMACHY data, Atmos. Meas. Tech., 8, 2589-2608, https://doi.org/10.5194/amt-8-2589-2015, 2015.

Köhler, P., Frankenberg, C., Magney, T. S., Guanter, L., Joiner, J., and Landgraf, J.: Global Retrievals of Solar-Induced Chlorophyll Fluorescence With TROPOMI: First Results and Intersensor Comparison to OCO-2, Geophys. Res. Lett., 45, 1045610463, https://doi.org/10.1029/2018gl079031, 2018.

Kuze, A., Suto, H., Nakajima, M., and Hamazaki, T.: Thermal and near infrared sensor for carbon observation Fouriertransform spectrometer on the Greenhouse Gases Observing Satellite for greenhouse gases monitoring, Appl. Optics, 48, 6716-33, https://doi.org/10.1364/AO.48.006716, 2009.

Lee, J. E., Frankenberg, C., van der Tol, C., Berry, J. A., Guanter, L., Boyce, C. K., Fisher, J. B., Morrow, E., Worden, J. R., Asefi, S., Badgley, G., and Saatchi, S.: Forest productivity and water stress in Amazonia: observations from GOSAT chlorophyll fluorescence, Proc. Biol. Sci., 280, 20130171, https://doi.org/10.1098/rspb.2013.0171, 2013.

Li, X. and Xiao, J.: A Global, 0.05-Degree Product of SolarInduced Chlorophyll Fluorescence Derived from OCO-2, MODIS, and Reanalysis Data, Remote Sensing, 11, 517, https://doi.org/10.3390/rs11050517, 2019.

Liu, L., Guan, L., and Liu, X.: Directly estimating diurnal changes in GPP for $\mathrm{C}_{3}$ and $\mathrm{C}_{4}$ crops using far-red suninduced chlorophyll fluorescence, Agr. Forest Meteorol., 232, 19, https://doi.org/10.1016/j.agrformet.2016.06.014, 2017.

Luus, K. A., Commane, R., Parazoo, N. C., Benmergui, J., Euskirchen, E. S., Frankenberg, C., Joiner, J., Lindaas, J., Miller, C. E., Oechel, W. C., Zona, D., Wofsy, S., and Lin, J. C.: Tundra photosynthesis captured by satellite-observed solar-induced chlorophyll fluorescence, Geophys. Res. Lett., 44, 1564-1573, https://doi.org/10.1002/2016g1070842, 2017.

Magney, T. S., Frankenberg, C., Fisher, J. B., Sun, Y., North, G. B., Davis, T. S., Kornfeld, A., and Siebke, K.: Connecting active to passive fluorescence with photosynthesis: a method for evaluating remote sensing measurements of Chl fluorescence, New Phytol., 215, 1594-1608, https://doi.org/10.1111/nph.14662, 2017.

Magney, T. S., Bowling, D. R., Logan, B. A., Grossmann, K., Stutz, J., Blanken, P. D., Burns, S. P., Cheng, R., Garcia, M. A., Köhler, P., Lopez, S., Parazoo, N. C., Raczka, B., Schimel, D., and Frankenberg, C.: Mechanistic evidence for tracking the seasonality of photosynthesis with solar-induced fluorescence, P. Natl. Acad. Sci. USA, 116, 11640-11645, https://doi.org/10.1073/pnas.1900278116, 2019a.
Magney, T. S., Frankenberg, C., Köhler, P., North, G., Davis, T. S., Dold, C., Dutta, D., Fisher, J. B., Grossmann, K., Harrington, A., Hatfield, J., Stutz, J., Sun, Y., and PorcarCastell, A.: Disentangling changes in the spectral shape of chlorophyll fluorescence: Implications for remote sensing of photosynthesis, J. Geophys. Res.-Biogeo., 124, 1491-1507, https://doi.org/10.1029/2019jg005029, 2019b.

Mahadevan, P., Wofsy, S. C., Matross, D. M., Xiao, X., Dunn, A. L., Lin, J. C., Gerbig, C., Munger, J. W., Chow, V. Y., and Gottlieb, E. W.: A satellite-based biosphere parameterization for net ecosystem $\mathrm{CO}_{2}$ exchange: Vegetation Photosynthesis and Respiration Model (VPRM), Global Biogeochem. Cy., 22, GB2005, https://doi.org/10.1029/2006gb002735, 2008.

Mohammed, G. H., Colombo, R., Middleton, E. M., Rascher, U., van der Tol, C., Nedbal, L., Goulas, Y., Perez-Priego, O., Damm, A., Meroni, M., Joiner, J., Cogliati, S., Verhoef, W., Malenovsky, Z., Gastellu-Etchegorry, J.-P., Miller, J. R., Guanter, L., Moreno, J., Moya, I., Berry, J. A., Frankenberg, C., and Zarco-Tejada, P. J.: Remote sensing of solar-induced chlorophyll fluorescence (SIF) in vegetation: 50 years of progress, Remote Sens. Environ., 231, 111177, https://doi.org/10.1016/j.rse.2019.04.030, 2019.

Monahan, A. H., Fyfe, J. C., Ambaum, M. H. P., Stephenson, D. B., and North, G. R.: Empirical Orthogonal Functions: The Medium is the Message, J. Climate, 22, 6501-6514, https://doi.org/10.1175/2009jcli3062.1, 2009.

Monteith, J. L.: Solar Radiation and Productivity in Tropical Ecosystems, J. Appl. Ecol., 9, 747-766, 1972.

Parazoo, N. C., Bowman, K., Fisher, J. B., Frankenberg, C., Jones, D. B., Cescatti, A., Perez-Priego, O., Wohlfahrt, G., and Montagnani, L.: Terrestrial gross primary production inferred from satellite fluorescence and vegetation models, Glob. Change Biol., 20, 3103-3121, https://doi.org/10.1111/gcb.12652, 2014.

Parazoo, N. C., Arneth, A., Pugh, T. A. M., Smith, B., Steiner, N., Luus, K., Commane, R., Benmergui, J., Stofferahn, E., Liu, J., Rodenbeck, C., Kawa, R., Euskirchen, E., Zona, D., Arndt, K., Oechel, W., and Miller, C.: Spring photosynthetic onset and net $\mathrm{CO}_{2}$ uptake in Alaska triggered by landscape thawing, Glob. Change Biol., 24, 3416-3435, https://doi.org/10.1111/gcb.14283, 2018.

Parazoo, N. C., Frankenberg, C., Kohler, P., Joiner, J., Yoshida, Y., Magney, T., Sun, Y., and Yadav, V.: Towards a Harmonized Long-Term Spaceborne Record of Far-Red SolarInduced Fluorescence, J. Geophys. Res.-Biogeo., 124, 25182539, https://doi.org/10.1029/2019jg005289, 2019.

Peters, W., Jacobson, A. R., Sweeney, C., Andrews, A. E., Conway, T. J., Masarie, K., Miller, J. B., Bruhwiler, L. M., Petron, G., Hirsch, A. I., Worthy, D. E., van der Werf, G. R., Randerson, J. T., Wennberg, P. O., Krol, M. C., and Tans, P. P.: An atmospheric perspective on North American carbon dioxide exchange: CarbonTracker, P. Natl. Acad. Sci. USA, 104, 1892518930, https://doi.org/10.1073/pnas.0708986104, 2007.

Reichstein, M., Falge, E., Baldocchi, D., Papale, D., Aubinet, M., Berbigier, P., Bernhofer, C., Buchmann, N., Gilmanov, T., Granier, A., Grunwald, T., Havrankova, K., Ilvesniemi, H., Janous, D., Knohl, A., Laurila, T., Lohila, A., Loustau, D., Matteucci, G., Meyers, T., Miglietta, F., Ourcival, J.-M., Pumpanen, J., Rambal, S., Rotenberg, E., Sanz, M., Tenhunen, J., Seufert, G., Vaccari, F., Vesala, T., Yakir, D., and Valentini, R.: On the separation of net ecosystem exchange into assimilation and 
ecosystem respiration: review and improved algorithm, Glob. Change Biol., 11, 1424-1439, https://doi.org/10.1111/j.13652486.2005.001002.x, 2005.

Schaaf, C. B., Gao, F., Strahler, A. H., Lucht, W., Li, X., Tsang, T., Strugnell, N. C., Zhang, X., Jin, Y., Muller, J.-P., Lewis, P., Barnsley, M., Hobson, P., Disney, M., Roberts, G., Dunderdale, M., Doll, C., d'Entremont, R. P., Hu, B., Liang, S., Privette, J. L., and Roy, D.: First operational BRDF, albedo nadir reflectance products from MODIS, Remote Sens. Environ., 83, 135-148, https://doi.org/10.1016/s0034-4257(02)00091-3, 2002.

Sellers, P. J.: Canopy reflectance, photosynthesis and transpiration, Int. J. Remote Sens., 6, 1335-1372, https://doi.org/10.1080/01431168508948283, 1985.

Sellers, P. J., Mintz, Y., Sud, Y. C., and Dalcher, A.: A Simple Biosphere Model (SIB) for Use within General Circulation Models, J. Atmos. Sci., 43, 505-531, https://doi.org/10.1175/15200469(1986)043<0505:asbmfu>2.0.co;2, 1986.

Strahler, A., Muchoney, D., Borak, J., Friedl, F., Gopal, S., Lambin, L., and Moody, A.: MODIS Land Cover Product Algorithm Theoretical Basis Document (ATBD), Tech. rep., Center for Remote Sensing, Department of Geography, Boston University, available at: https://modis.gsfc.nasa.gov/data/atbd/atbd_ mod12.pdf (last access: 2 October 2019), 1999.

Sun, K., Zhu, L., Cady-Pereira, K., Chan Miller, C., Chance, K., Clarisse, L., Coheur, P.-F., González Abad, G., Huang, G., Liu, X., Van Damme, M., Yang, K., and Zondlo, M.: A physicsbased approach to oversample multi-satellite, multispecies observations to a common grid, Atmos. Meas. Tech., 11, 6679-6701, https://doi.org/10.5194/amt-11-6679-2018, 2018.

Sun, Y., Frankenberg, C., Wood, J. D., Schimel, D. S., Jung, M., Guanter, L., Drewry, D. T., Verma, M., Porcar-Castell, A., Griffis, T. J., Gu, L., Magney, T. S., Kohler, P., Evans, B., and Yuen, K.: OCO-2 advances photosynthesis observation from space via solar-induced chlorophyll fluorescence, Science, 358, eaam5747, https://doi.org/10.1126/science.aam5747, 2017.

Sun, Y., Frankenberg, C., Jung, M., Joiner, J., Guanter, L., Köhler, P., and Magney, T.: Overview of Solar-Induced chlorophyll Fluorescence (SIF) from the Orbiting Carbon Observatory-2: Retrieval, cross-mission comparison, and global monitoring for GPP, Remote Sens. Environ., 209, 808-823, https://doi.org/10.1016/j.rse.2018.02.016, 2018.

Tans, P. P., Fung, I. Y., and Takahashi, T.: Observational contrains on the global atmospheric $\mathrm{CO}_{2}$ budget, Science, 247, 1431-1438, https://doi.org/10.1126/science.247.4949.1431, 1990.

Turner, A. J., Koehler, P., Magney, T. S., Frankenberg, C., Fung, I., and Cohen, R. C.: Downscaled 500-m TROPOMI SIF over California, Caltech, https://doi.org/10.22002/d1.1327, 2019.

Tyler, C. M., Kuhn, B., and Davis, F. W.: Demography and recruitment limitations of three oak species in California, Q. Rev. Biol., 81, 127-152, 2006.

University of California at Davis: Rice Production Manual, Tech. rep., California Rice Production Workshop, Davis, CA, available at: http://rice.ucanr.edu/files/288581.pdf (last access: 2 October 2019), 2018.

USDA: National Agricultural Statistics Service Cropland Data Layer: Published crop-specific data layer, available at: https: //nassgeodata.gmu.edu/CropScape/ (last access: 2 January 2020), 2018
USGCRP: Second State of the Carbon Cycle Report (SOCCR2): A Sustained Assessment Report, Tech. rep., U.S. Global Change Research Program, https://doi.org/10.7930/SOCCR2.2018, 2018.

Veefkind, J. P., Aben, I., McMullan, K., Förster, H., de Vries, J., Otter, G., Claas, J., Eskes, H. J., de Haan, J. F., Kleipool, Q., van Weele, M., Hasekamp, O., Hoogeveen, R., Landgraf, J., Snel, R., Tol, P., Ingmann, P., Voors, R., Kruizinga, B., Vink, R., Visser, H., and Levelt, P. F.: TROPOMI on the ESA Sentinel-5 Precursor: A GMES mission for global observations of the atmospheric composition for climate, air quality and ozone layer applications, Proc. SPIE, 120, 70-83, https://doi.org/10.1016/j.rse.2011.09.027, 2012.

Walther, S., Voigt, M., Thum, T., Gonsamo, A., Zhang, Y., Kohler, P., Jung, M., Varlagin, A., and Guanter, L.: Satellite chlorophyll fluorescence measurements reveal large-scale decoupling of photosynthesis and greenness dynamics in boreal evergreen forests, Glob. Change Biol., 22, 2979-2996, https://doi.org/10.1111/gcb.13200, 2016.

$\mathrm{Xu}, \mathrm{L}$. and Baldocchi, D. D.: Seasonal trends in photosynthetic parameters and stomatal conductance of blue oak (Quercus douglasii) under prolonged summer drought and high temperature, Tree Physiol, 23, 865-877, https://doi.org/10.1093/treephys/23.13.865, 2003.

$\mathrm{Xu}$, L. and Baldocchi, D. D.: Seasonal variation in carbon dioxide exchange over a Mediterranean annual grassland in California, Agr. Forest Meteorol., 123, 79-96, https://doi.org/10.1016/j.agrformet.2003.10.004, 2004.

$\mathrm{Xu}$, L., Baldocchi, D. D., and Tang, J.: How soil moisture, rain pulses, and growth alter the response of ecosystem respiration to temperature, Global Biogeochem. Cy., 18, GB4002, https://doi.org/10.1029/2004gb002281, 2004.

Yang, H., Yang, X., Zhang, Y., Heskel, M. A., Lu, X., Munger, J. W., Sun, S., and Tang, J.: Chlorophyll fluorescence tracks seasonal variations of photosynthesis from leaf to canopy in a temperate forest, Glob. Change Biol., 23, 2874-2886, https://doi.org/10.1111/gcb.13590, 2017.

Yang, K., Ryu, Y., Dechant, B., Berry, J. A., Hwang, Y., Jiang, C., Kang, M., Kim, J., Kimm, H., Kornfeld, A., and Yang, X.: Sun-induced chlorophyll fluorescence is more strongly related to absorbed light than to photosynthesis at half-hourly resolution in a rice paddy, Remote Sens. Environ., 216, 658-673, https://doi.org/10.1016/j.rse.2018.07.008, 2018.

Yang, P. and van der Tol, C.: Linking canopy scattering of far-red sun-induced chlorophyll fluorescence with reflectance, Remote Sens. Environ., 209, 456-467, https://doi.org/10.1016/j.rse.2018.02.029, 2018.

Yang, X., Tang, J., Mustard, J. F., Lee, J.-E., Rossini, M., Joiner, J., Munger, J. W., Kornfeld, A., and Richardson, A. D.: Solarinduced chlorophyll fluorescence that correlates with canopy photosynthesis on diurnal and seasonal scales in a temperate deciduous forest, Geophys. Res. Lett., 42, 2977-2987, https://doi.org/10.1002/2015g1063201, 2015.

Yu, L., Wen, J., Chang, C. Y., Frankenberg, C., and Sun, Y.: HighResolution Global Contiguous SIF of OCO-2, Geophys. Res. Lett., 46, 1449-1458, https://doi.org/10.1029/2018gl081109, 2019. 
Zeng, Y., Badgkey, G., Dechant, B., Ryu, Y., Chen, M., and Berry, J. A.: A practical approach for estimating the escape ratio of near-infrared solar-induced chlorophyll fluorescence, Remote Sens. Environ., 232, 111209, https://doi.org/10.1016/j.rse.2019.05.028, 2019.

Zhang, Y., Joiner, J., Alemohammad, S. H., Zhou, S., and Gentine, P.: A global spatially contiguous solar-induced fluorescence (CSIF) dataset using neural networks, Biogeosciences, 15, 57795800, https://doi.org/10.5194/bg-15-5779-2018, 2018.

Zhu, L., Jacob, D. J., Mickley, L. J., Marais, E. A., Cohan, D. S., Yoshida, Y., Duncan, B. N., Gonzalez Abad, G., and Chance, K. V.: Anthropogenic emissions of highly reactive volatile organic compounds in eastern Texas inferred from oversampling of satellite (OMI) measurements of HCHO columns, Environ. Res. Lett., 9, 114004, https://doi.org/10.1088/17489326/9/11/114004, 2014.

Zoogman, P., Liu, X., Suleiman, R. M., Pennington, W. F., Flittner, D. E., Al-Saadi, J. A., Hilton, B. B., Nicks, D. K., Newchurch, M. J., Carr, J. L., Janz, S. J., Andraschko, M. R., Arola, A., Baker, B. D., Canova, B. P., Chan Miller, C., Cohen, R. C., Davis, J. E., Dussault, M. E., Edwards, D. P., Fishman, J., Ghulam, A., Gonzalez Abad, G., Grutter, M., Herman, J. R., Houck, J., Jacob, D. J., Joiner, J., Kerridge, B. J., Kim, J., Krotkov, N. A., Lamsal, L., Li, C., Lindfors, A., Martin, R. V., McElroy, C. T., McLinden, C., Natraj, V., Neil, D. O., Nowlan, C. R., O'Sullivan, E. J., Palmer, P. I., Pierce, R. B., Pippin, M. R., Saiz-Lopez, A., Spurr, R. J. D., Szykman, J. J., Torres, O., Veefkind, J. P., Veihelmann, B., Wang, H., Wang, J., and Chance, K.: Tropospheric emissions: Monitoring of pollution (TEMPO), J. Quant. Spectrosc. Ra., 186, 17-39, https://doi.org/10.1016/j.jqsrt.2016.05.008, 2017.
Zuromski, L. M., Bowling, D. R., Köhler, P., Frankenberg, C., Goulden, M. L., Blanken, P. D., and Lin, J. C.: SolarInduced Fluorescence Detects Interannual Variation in Gross Primary Production of Coniferous Forests in the Western United States, Geophys. Res. Lett., 45, 7184-7193, https://doi.org/10.1029/2018g1077906, 2018. 